\title{
A Bayesian network to predict coastal vulnerability to sea level rise
}

\author{
Benjamin T. Gutierrez, ${ }^{1}$ Nathaniel G. Plant, ${ }^{2}$ and E. Robert Thieler ${ }^{1}$ \\ Received 28 September 2010; revised 28 January 2011; accepted 9 February 2011; published 22 April 2011.
}

[1] Sea level rise during the 21 st century will have a wide range of effects on coastal environments, human development, and infrastructure in coastal areas. The broad range of complex factors influencing coastal systems contributes to large uncertainties in predicting long-term sea level rise impacts. Here we explore and demonstrate the capabilities of a Bayesian network $(\mathrm{BN})$ to predict long-term shoreline change associated with sea level rise and make quantitative assessments of prediction uncertainty. A BN is used to define relationships between driving forces, geologic constraints, and coastal response for the U.S. Atlantic coast that include observations of local rates of relative sea level rise, wave height, tide range, geomorphic classification, coastal slope, and shoreline change rate. The BN is used to make probabilistic predictions of shoreline retreat in response to different future sea level rise rates. Results demonstrate that the probability of shoreline retreat increases with higher rates of sea level rise. Where more specific information is included, the probability of shoreline change increases in a number of cases, indicating more confident predictions. A hindcast evaluation of the BN indicates that the network correctly predicts $71 \%$ of the cases. Evaluation of the results using Brier skill and log likelihood ratio scores indicates that the network provides shoreline change predictions that are better than the prior probability. Shoreline change outcomes indicating stability $(-1<$ rate $<1 \mathrm{~m} / \mathrm{yr})$ or erosion (rate $<-1 \mathrm{~m} / \mathrm{yr}$ ) tend to occur for two sets of input scenarios. Stable shoreline change rates occur mainly for low rates of relative sea level rise and occur in low-vulnerability geomorphic settings. Rates indicating erosion result for cases where the rate of relative sea level rise is high and moderate-to-high vulnerability geomorphic settings occur. In contrast, accretion (rate $>1 \mathrm{~m} / \mathrm{yr}$ ) was not well predicted. We find that BNs can assimilate important factors contributing to coastal change in response to sea level rise and can make quantitative, probabilistic predictions that can be applied to coastal management decisions.

Citation: Gutierrez, B. T., N. G. Plant, and E. R. Thieler (2011), A Bayesian network to predict coastal vulnerability to sea level rise, J. Geophys. Res., 116, F02009, doi:10.1029/2010JF001891.

\section{Introduction}

[2] Sea level rise is a major climate change impact that will have a wide range of effects on coastal environments [Douglas, 2001; Solomon et al., 2007; FitzGerald et al., 2008]. During the 21 st century, the rate of sea level rise is projected to be several times higher than that measured over the past century [Meehl et al., 2007; Rahmstorf, 2007]. Recent projections suggest that sea level may be $\sim 0.6-1.5 \mathrm{~m}$ higher than present by 2100 [Rahmstorf, 2007; Horton et al., 2008; Jevrejeva et al., 2010], and $\sim 2 \mathrm{~m}$ higher only under extreme scenarios [Pfeffer et al., 2008; Vermeer and Rahmstorf, 2009; Grinsted et al., 2010]. There will also be substantial global and regional variations in relative sea level change, both positive and negative, due to a range of geophysical, gravitational, and oceanographic processes [Peltier,

\footnotetext{
${ }^{1}$ U.S. Geological Survey, Woods Hole, Massachusetts, USA

${ }^{2}$ U.S. Geological Survey, St. Petersburg, Florida, USA.
}

This paper is not subject to U.S. copyright. Published in 2011 by the American Geophysical Union.
1994; Bamber et al., 2009; Hu et al., 2009; Milne et al., 2009; Mitrovica et al., 2009; Yin et al., 2009].

[3] Sea level rise impacts will be widespread and include land loss from coastal erosion and inundation; migration of coastal landforms; increased frequency, duration and elevation of storm-surge flooding; wetland loss; and changes in coastal aquifer hydrology. There will be far reaching impacts on human populations [McGranahan et al., 2007; Nicholls et al., 2007]. Human infrastructure and development in the coastal zone can also exacerbate the impact to natural systems [Nicholls et al., 2007]. Consequently, there is a longrecognized need to predict long-term sea level rise impacts to make coastal management decisions [Titus et al., 2009].

[4] Previous efforts to assess the impact of sea level rise on coastal erosion and inundation include both quantitative and qualitative approaches. Quantitative approaches have attempted to measure the amount of land below the elevation of specific sea level rise scenarios using a "bathtub" approach wherein an elevation data set is intersected with a raised sea level [e.g., Schneider and Chen, 1980; Smith and Tirpak, 1989; Najjar et al., 2000; Titus and Richman, 2001; McGranahan et al., 2007]. This method provides a crude estimate of the potential extent of land that could be vulner- 
able to sea level rise. However, there are large uncertainties using this approach that are related to technical limitations in the topographic data [Gesch et al., 2009; Gesch, 2009], as well as the inability to take into account dynamic processes such as coastal erosion and deposition, landform migration, and wetland accretion [Cahoon et al., 2009; Gutierrez et al., 2009].

[5] Other quantitative approaches estimate the extent of coastal erosion [e.g., Gornitz et al., 2001] and sometimes couple this with the potential for inundation [Kana et al., 1984; Leatherman, 1984]. These methods often rely on simple calculations such as the Bruun Rule [Bruun, 1962; Gornitz et al., 2001] and/or shoreline change rate extrapolations. Both methods rely on assumptions, such as existence of an equilibrium beach profile, and/or uniform alongshore sediment transport, that may be inaccurate [e.g., Pilkey and Davis, 1987; Carter and Woodroffe, 1994; Thieler et al., 2000; Cooper and Pilkey, 2004]. More recent coastal landform modeling efforts incorporate a range of information about the underlying geology, hydrodynamic characteristics, and coastal sediment budget [Cowell et al., 1995; Stolper et al., 2005; McNamara and Werner, 2008; Masetti et al., 2008]. Alternatively, coastal vulnerability indices allow users integrate a number of parameters that can be ranked and combined into a risk index as a measure of potential for a sea level rise impact [Gornitz and Kanciruk, 1989; Shaw et al., 1998; Thieler and Hammar-Klose, 1999; Pendleton et al., 2010; Abuodha and Woodroffe, 2010], but the results of these indices are not readily translated into a quantifiable impact.

[6] As noted in some sea level rise impact assessments, there is a great deal of uncertainty associated with climate change itself [e.g., Nicholls et al., 2007], as well as uncertainties in predicting coastal response even if sea level rise was perfectly predictable [Ranasinghe and Stive, 2009]. In particular, many of the predictive approaches that have been used do not specifically address uncertainties. Some fraction of uncertainty in predicting the coastal response to sea level rise is unavoidable. Relatively few researchers have explored probabilistic approaches to manage uncertainty associated with assessments evaluating long-term shoreline change in response to sea level rise [Cowell and Zeng, 2003; Cowell et al., 2006]. As is abundantly clear from Intergovernmental Panel on Climate Change (IPCC) assessments [e.g., Houghton et al., 2001; Solomon et al., 2007] and studies of climate change decision making [National Research Council (NRC), 2009, 2010], communication of this uncertainty is an absolute requirement in order to apply existing scientific knowledge to critical coastal environmental and societal management problems. There is a critical need to develop an improved capability for sea level rise impact assessment and to communicate information in a way that explicitly addresses uncertainty [Tribbia and Moser, 2008; NRC, 2009].

[7] In this paper, we develop a Bayesian network (BN) to describe quantitatively the probability of different shoreline change rates given knowledge of several factors that define a particular shoreline setting. The BN-based approach differs from other approaches that have been applied to this problem in the past which rely on simple models to calculate shoreline change resulting from sea level rise constrained by strict assumptions [Bruun, 1962] or estimation of straight forward statistical relationships using strict criteria to subsample data sets to isolate observations where it is assumed that long-term sea level rise is the dominant factor contributing to shoreline change [Zhang et al., 2004]. The BN approach provides a framework for applying Bayes' rule [Bayes, 1763; Jensen and Nielsen, 2007] which allows users to evaluate the probability of a specific outcome based on causal relationships between a wider range of variables deemed important by users. This approach has been used in the artificial intelligence, medical, and ecological communities for at least a decade to evaluate and translate scientific information and/or expert judgments into probabilistic terms (see review by Berger [2000]). In the earth sciences, BNs have been used to address ecological questions [Borsuk et al., 2004; McCann et al., 2006; Pollino et al., 2007; Ticehurst et al., 2007; Wilson et al., 2008], volcanic risks [Aspinall et al., 2003]; and science and management of hydrologic systems [Castelletti and Soncini-Sessa, 2007a, 2007b; Martin de Santa Olalla et al., 2007; Mount and Stott, 2008]. The BN approach is also useful because it facilitates participation between scientists and stakeholders when applied to management issues [Henriksen et al., 2007].

[8] We use an existing data set that was compiled to evaluate potential sea level rise vulnerability for the Atlantic coast of the United States for our development and application of a BN [Thieler and Hammar-Klose, 1999, hereafter THK99]. The THK99 data set consists of long-term relative sea level rise, long-term shoreline change rates, mean wave height, mean tidal range, the geomorphic setting, and coastal slope. Because the relative sea level rise and long-term shoreline change data consist of measurements spanning several decades to a century or more, we focus on long-term shoreline change rates as opposed to those related to individual storms. Our objective is to evaluate whether long-term shoreline changes (50-100 years) can be predicted based on knowledge of long-term average forcing conditions (50-100 years) and boundary conditions.

[9] In section 2, we review the Bayesian approach, our implementation of a $\mathrm{BN}$, and the data used in our analysis. Section 3 presents the results using the BN to describe the prior probability of shoreline change, which in our case reflects the probability of shoreline change considering all the information in the data set. In addition, the results of a hindcast comparison and skill test of observed and predicted shoreline change rates are reviewed. Section 3 also evaluates how the predicted probability of shoreline change depends on the degree of knowledge of the input variables. In particular, we evaluate how the probability of shoreline change varies in response to the selection of specific sea level rise scenarios. Section 4 discusses the implication of the results, the potential sources of error, and the benefits and limitations of this approach. Section 5 summarizes our conclusions.

\section{Methods}

[10] We use a BN to examine the probabilities of long-term shoreline change given knowledge of several variables in the THK99 data set described in section 2.2 [Thieler and Hammar-Klose, 1999; Hammar-Klose and Thieler, 2001] that are expected to influence long-term shoreline change. The implied model is

$$
R(\vec{x}, t)=\text { funct. }[S(\vec{x}, t), W(\vec{x}, t), T(\vec{x}, t), G(\vec{x}, t), \beta(\vec{x}, t)],
$$




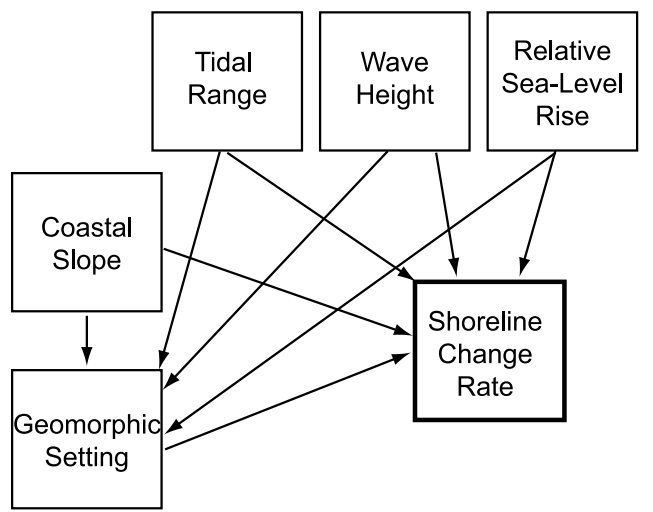

Figure 1. Structure of the Bayesian network (BN) used in this paper. Here the rate of relative sea level rise, mean wave height, and tidal range are considered driving forces; the coastal slope and geomorphic setting are considered boundary conditions; and the shoreline change rate is considered to be the response variable or vulnerability indicator.

where $R$ is the long-term shoreline change rate and depends on spatial location vector $\vec{x}$ (i.e., latitude and longitude) and time. The shoreline change rate response is assumed to depend on long-term ( $\sim 50-100$ years) averaged values of the rate of relative sea level rise $(S)$, mean wave height $(W)$, tidal range $(T)$, geomorphic setting $(G)$, and coastal slope $(\beta)$. Our implicit consideration of long-term processes means that the time variable resolves slow variations in the system such as climate change and the geomorphic response. The slope term captures large-scale landscape evolution over much longer time scales (hundreds to thousands of years). Our hypothesis is that the functional relationship can be learned from a historical data set and cast in terms of a probabilistic estimate in the form

$$
p(R \mid\{S, W, T, G, \beta\})=\text { funct. }[p(S, W, T, G, \beta)] .
$$

That is, the conditional probability distribution of the shoreline change response to a particular set of inputs can be obtained from the joint probability of the historical observations. The functional equation is derived using Bayes' theorem and using a BN informed by the six variables in the THK99 data set.

\subsection{Construction of a Bayesian Network}

[11] Bayesian networks are an application of Bayes' theorem that relates the probability of one event $R$ given the occurrence of another event $O$ [Bayes, 1763; Gelman et al., 2004]:

$$
p\left(R_{i} \mid O_{j}\right)=\frac{p\left(O_{j} \mid R_{i}\right) \cdot p\left(R_{i}\right)}{p\left(O_{j}\right)} .
$$

Here, the left-hand side of equation (3) is the conditional probability of a particular response, $R_{i}$, given a set of observations $O_{j}$. A particular response might include the joint occurrence of a particular rate of sea level rise and a particular rate of shoreline change. The $i$ th response scenario is just one of a finite number of such scenarios that can be considered. Likewise, the $j$ th observation set represents one of many possible observations sets. The first term in the numerator of the right hand side of the equation is the likelihood of the observations if the response is known. In essence, this term indicates the strength of the correlation between observation and response. The correlation is high if the observations are accurate (i.e., low observational uncertainty) and if the particular response variables are actually sensitive to the observed variables. The second term in the numerator is the prior probability of the response. That is, it is the probability of a particular response integrated over all expected observation scenarios. In our application, this represents a historical "climatology" that lacks geographic and temporal specificity. The denominator is a normalization factor to account for the likelihood of the observations.

[12] BNs combine Bayes' rule with graphical models of a system, such as physical or biological systems [Cowell, 1999; Heckerman, 1999; Jensen and Nielsen, 2007; Mount and Stott, 2008]. We used the Netica software package (Norsys, Netica v. 4.09, www.norsys.com) to construct a BN for the THK99 data, assuming simple causal relationships between the six different variables to construct the $\mathrm{BN}$ (Figure 1). The six variables, often referred to as decision nodes in a $\mathrm{BN}$, are divided into three categories: driving forces, geological boundary conditions, and a response variable that is used as a vulnerability indicator. The relative sea level rise rate, wave height, and tidal range are considered driving forces. The geomorphic setting and coastal slope are considered geological boundary conditions. We used shoreline change rate as the response variable. Each node (i.e., variable) is resolved by five classes corresponding to risk categories

\begin{tabular}{|c|c|c|c|c|c|}
\hline Variable & 1 & 2 & 3 & 4 & 5 \\
\hline Geomorphology & $\begin{array}{c}1 \text { - very low } \\
\text { risk rocky, } \\
\text { cliffed coasts, fjords }\end{array}$ & $\begin{array}{l}2-\text { low-risk } \\
\text { medium cliffs, } \\
\text { indented coasts }\end{array}$ & $\begin{array}{l}3-\text { moderate } \\
\text { risk low cliffs, } \\
\text { glacial drift, } \\
\text { alluvial plains }\end{array}$ & $\begin{array}{l}4 \text { - high-risk } \\
\text { cobble beaches, } \\
\text { estuarine and } \\
\text { lagoonal coasts }\end{array}$ & $\begin{array}{c}5 \text { - very high } \\
\text { risk barrier beaches, } \\
\text { sand beaches, salt marsh, } \\
\text { mud flats, deltas, } \\
\text { mangroves, coral reefs }\end{array}$ \\
\hline Shoreline change (m/yr) & $>2.0$ & $1.0-2.0$ & $-1.0-1.0$ & $-2.0--1.0$ & $<-2.0$ \\
\hline Coastal slope $(\%)$ & $>0.2$ & $0.2-0.07$ & $0.07-0.04$ & $0.04-0.025$ & $<0.025$ \\
\hline Relative sea level change $(\mathrm{mm} / \mathrm{yr})$ & $<1.8$ & $1.8-2.5$ & $2.5-2.95$ & $2.95-3.16$ & $>3.16$ \\
\hline Mean wave height $(\mathrm{m})$ & $<0.55$ & $0.55-0.85$ & $0.85-1.05$ & $1.05-1.25$ & $>1.25$ \\
\hline Mean tidal range $(\mathrm{m})$ & $>6.0$ & $4.1-6.0$ & $2.0-4.0$ & $1.0-1.9$ & $<1.0$ \\
\hline
\end{tabular}

Table 1. Variables Used in the $\mathrm{BN}^{\mathrm{a}}$

${ }^{\mathrm{a}}$ The numbers $1-5$ are the binned values.

${ }^{\mathrm{b}}$ The ordinal ranking for geomorphology is based on the sea level rise vulnerability classification used by THK99. 
Table 2. Number of Data Points in the Categories Used in Each Node of the $\mathrm{BN}^{\mathrm{a}}$

\begin{tabular}{lccccc}
\hline \multicolumn{1}{c}{ Variable } & 1 & 2 & 3 & 4 & 5 \\
\hline Geomorphology & 318 & 54 & 234 & 414 & 1358 \\
Shoreline change (m/yr) & 111 & 76 & 1169 & 323 & 699 \\
Coastal slope (\%) & 331 & 515 & 781 & 523 & 228 \\
Relative sea level change (mm/yr) & 413 & 601 & 584 & 251 & 529 \\
Mean wave height (m) & 1 & 34 & 954 & 854 & 535 \\
Mean tidal range (m) & 0 & 59 & 456 & 749 & 1114 \\
\hline
\end{tabular}

${ }^{\mathrm{a}}$ The values are explained in Table 1.

defined in THK99 (see Table 1). Table 2 shows the distribution of the data in each of the five classes.

[13] In Figure 1, the arrows linking the driving forces and the boundary conditions represent our understanding of how these variables influence the shoreline change rate and one another. Although there are quantitative methods that can be used to define an optimal network structure for a BN [e.g., Jensen and Nielsen, 2007], network structure is a matter of judgment that strives to achieve a network that reflects expert knowledge, efficient performance of the network, and stakeholder needs [Martin de Santa Olalla et al., 2007; Marcot et al., 2006]. We designed this network to ensure that the BN structure reflects our understanding of how the variables influence long-term shoreline change. Thus, the BN structure that we use represents our hypothesis, which will be tested with the available data.

\subsection{The THK99 Data Set}

[14] The six variables used in THK99 are defined for $5 \mathrm{~km}$ segments of the shoreline for the coastlines of the continental United States (Figure 2 and Table 1). The THK99 data were originally gridded to a shoreline data layer at $\sim 5 \mathrm{~km}$ resolution that included inland coastal waterways. For this study, we focused on the U.S. Atlantic coast and removed data points for inland waterways where no shoreline change data were available and to match the original extent of shoreline change data from Dolan et al. [1985], which form much of the basis for the long-term shoreline change rates in THK99. The input data comprise the ocean facing shores of the U.S. Atlantic coast from the Canadian border to Key West, Florida, and portions of Chesapeake and Delaware bays. The resulting BN predictions are applicable to the same spatial scale as the input. The BN resolves the values of the data according to the same divisions used in THK99 (Tables 1 and 2). As a result of the removal of inland waterways, our network is not trained on data having very high tidal range and very low wave height. Initial experiments indicated that retaining these divisions does not affect the accuracy of network outputs, so we retain these possible states for consistency and because they are a negligible computational burden. The variables are described briefly below and explained in detail in THK99 and Table 1.

[15] Relative sea level rise rate is computed by fitting a linear trend to National Ocean Service (NOS) long-term (50-100+ years) tide gauge observations and interpolating alongshore between stations. In the $\mathrm{BN}$ used here, the sea level rise rate is assumed to exert an influence on the geomorphic setting and the shoreline change rate.
[16] Mean wave height is computed from U.S. Army Corps of Engineers Wave Information Studies (WIS) hindcast data [Hubertz et al., 1996] and interpolated alongshore between WIS stations. Wave height reflects the wave climatology and potential sediment transport in a particular area and is assumed to influence the geomorphic setting and the shoreline change rate.

[17] Mean tidal range is computed from NOS tide gauges and interpolated alongshore between stations. Tidal range influences the characteristics of coastal landforms such as barrier islands [Hayes, 1979]. THK99 and Morton [2003] also point out that where storm surges may occur, regions with low tidal range can experience higher potential for inundation and consequently greater risk of dune breaching than areas with a higher tidal range. The tidal range is assumed to influence the geomorphic setting and the shoreline change rate.

[18] Geomorphic setting is based on an ordinal sea level rise vulnerability classification by Gornitz and Kanciruk [1989] and modified by THK99 to include division of

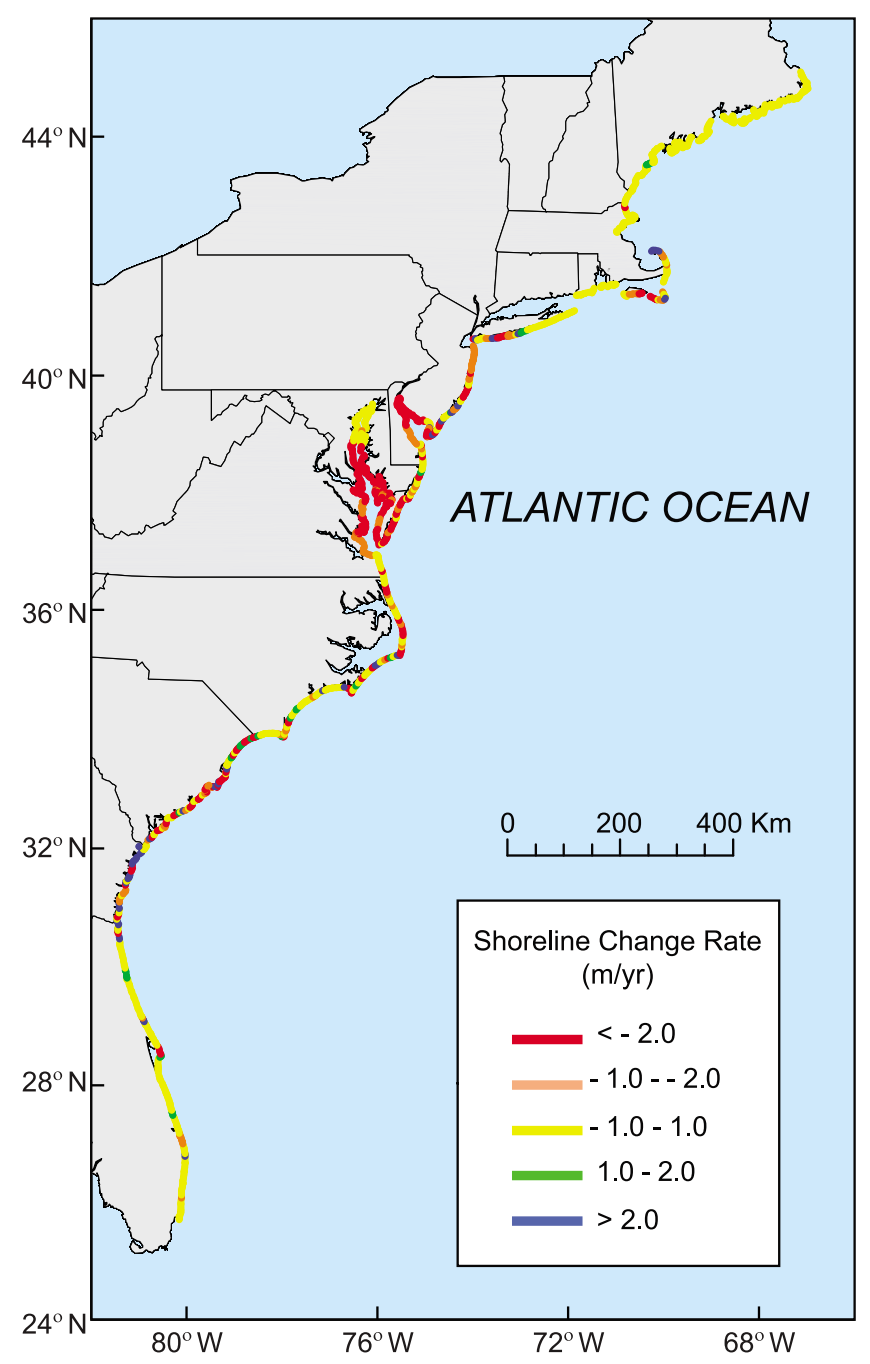

Figure 2. Map of shoreline change rates for the U.S. Atlantic coast showing the spatial extent of the THK99 data set that was used to train the $\mathrm{BN}$ used in this paper. 

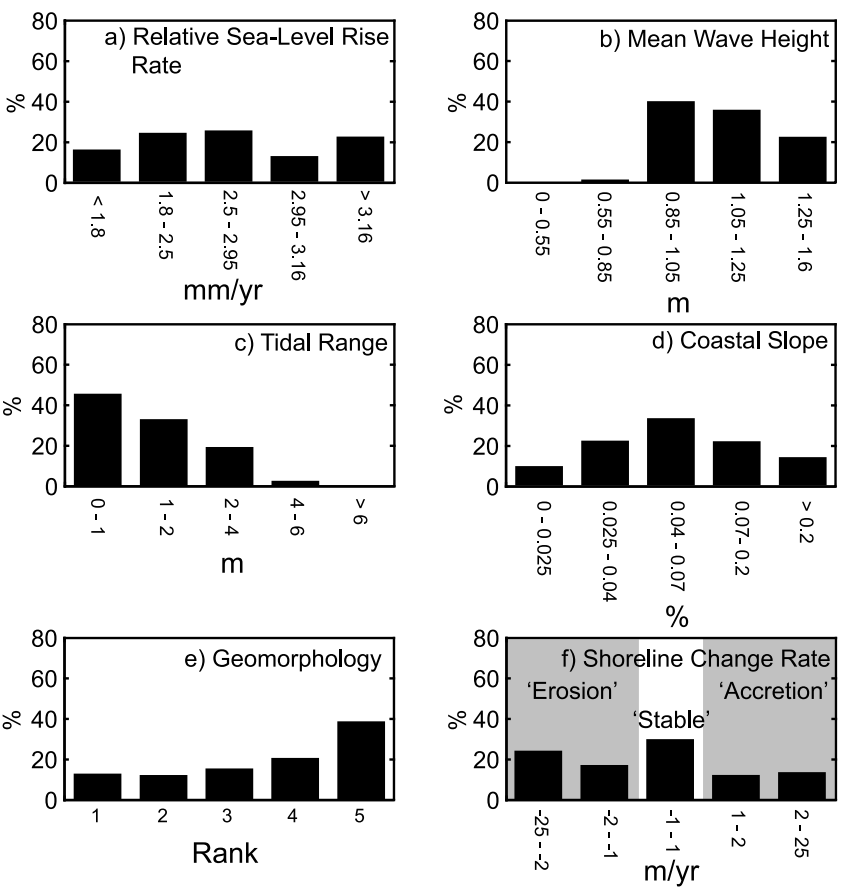

Figure 3. $(\mathrm{a}-\mathrm{f})$ Prior probability distributions for the variables in each node of the BN. Shading in Figure $3 \mathrm{f}$ identifies the three shoreline change rate designations used in this paper: erosion, rate $<-1 \mathrm{~m} / \mathrm{yr}$; stable, $-1 \mathrm{~m} / \mathrm{yr}<$ rate $<1 \mathrm{~m} / \mathrm{yr}$; and accretion, rate $>1 \mathrm{~m} / \mathrm{yr}$.

barrier islands into transgressive and regressive types [Nummedal, 1983]. Coastal landforms develop as a result of the interaction of many factors. It is assumed that the sea level rise rate, mean wave height, mean tidal range, and coastal slope all contribute to the development of a given coastal landform that can be identified as a distinct geomorphic setting, and that the geomorphic setting influences the shoreline change rate. Simplifying the THK99 definitions in this paper, geomorphic settings 1 and 2 are referred to as very low and low vulnerability settings, setting 3 is moderate vulnerability, and settings 4 and 5 are high and very high vulnerability settings, respectively (Table 1 ).

[19] Coastal slope is computed from gridded National Geophysical Data Center and U.S. Navy topographic and bathymetric elevation data extending approximately $50 \mathrm{~km}$ landward and seaward of the local shoreline. Coastal slope is a measure of the gradient of the substrate on which the local geomorphology has formed and influences the development of coastal landforms in a region [Roy et al., 1994]. Coastal slope can also affect the shoreline change rate as shallow gradients can result in greater horizontal displacement per unit rise in sea level [Pilkey and Davis, 1987]. Coastal slope is assumed to influence the geomorphic setting and the shoreline change rate.

[20] Shoreline change rate is a decadal- to centennial-scale historic rate of shoreline change based on data compiled by May et al. [1983] and Dolan et al. [1985] into the Coastal Erosion Information System (CEIS) [May et al., 1982] (Figure 2). The data in CEIS are drawn from a wide variety of sources, including published reports, historical shoreline change maps, field surveys and aerial photo analyses. How- ever, the lack of a standard method among coastal scientists for analyzing shoreline changes [Morton and Miller, 2005] has resulted in the inclusion of data utilizing a variety of reference features, measurement techniques, and rate-ofchange calculations. Thus, while CEIS represents the currently best available data for the entire Atlantic coast in a format amenable to this analysis, actual regional and local erosion rates may differ significantly [cf. May et al., 1983; Dolan et al., 1990]. We updated shoreline change data along the southern shore of Delaware Bay and the northern Chesapeake Bay with shoreline change rates from Dolan and Peatross [1992] due to possible gridding errors in the original THK99 data set. In the BN used here, the shoreline change rate is the response variable and is assumed to be influenced by the other variables in the network.

\section{Results}

[21] We examine several aspects of the $\mathrm{BN}$, focusing on evaluating our hypothesis described by equation (2) and demonstrating BN capabilities. A key objective in our evaluation of updated predictions is to understand the increase in predictive power (or decrease in uncertainty) when additional information or constraints are used to update the network. In the following cases, we examine whether the probability of shoreline change rate is less than $-1 \mathrm{~m} / \mathrm{yr}$ (erosion), between -1 and $1 \mathrm{~m} / \mathrm{yr}$ (stable or stability), or greater than $1 \mathrm{~m} / \mathrm{yr}$ (accretion).

\subsection{Prior Probabilities}

[22] The prior probability distribution of the variables in the THK99 data set has a diverse range of conditions represented in the input data (Figure 3). The shoreline change rates (our vulnerability indicator) are shown in Figure $3 \mathrm{f}$, with grey shading to indicate the erosion, stable, and accretion classifications defined above. In this case, the shoreline change rate probabilities can be thought of as a "climatological" average for the study area. The prior probability of a specific shoreline change rate, such as a rate indicating erosion, is simply the probability of this outcome considering all scenarios from the input data set. Here, the shoreline change outcome with the highest probability is erosion $(\mathrm{P}=42.5 \%)$. In comparison, the probabilities that shoreline change rates indicate stability or accretion are $30.5 \%$ and $27 \%$, respectively.

\subsection{The Influence of Relative Sea Level Rise Rate on Shoreline Change Rate}

[23] In this section, we explore several cases where we constrain the BN with specific relative sea level rise scenarios. These cases demonstrate how the posterior probability of shoreline change can change in comparison to the prior. Figure 4 illustrates the results of evaluating the posterior probability of erosion given a specified $100 \%$ probability that the rate of relative sea level rise is $>3.16 \mathrm{~mm} / \mathrm{yr}$ (Figure 4a). In comparison to the prior, the posterior probability of erosion increases to $57 \%$ while posterior probabilities indicating stability or accretion decrease to $18 \%$ and $25 \%$, respectively (Figure $4 \mathrm{f}$ ). The updated $\mathrm{BN}$ also allows us to identify the corresponding values of the other input variables that are associated with this scenario. In this case, the resulting probability distributions indicate the most probable mean wave height between 0.85 and $1.05 \mathrm{~m}$, tidal range 

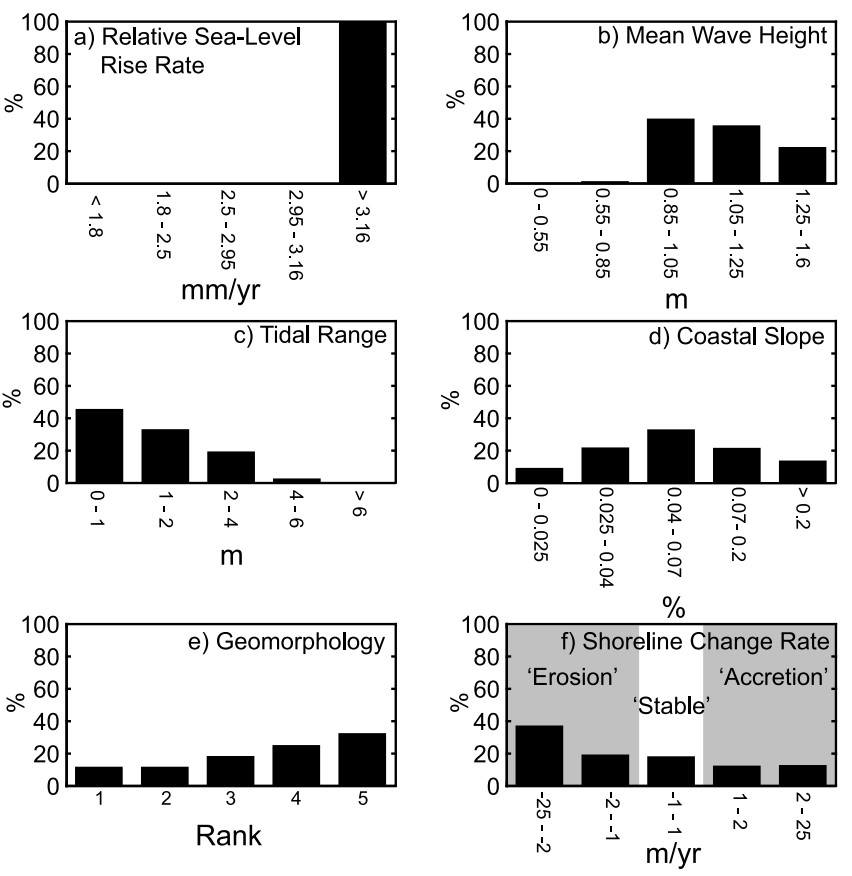

Figure 4. (a-f) Probability distributions for the variables in each node for the case where there is a $100 \%$ probability of the rate of relative sea level rise being $>3.16 \mathrm{~mm} / \mathrm{yr}$. Shaded regions in Figure $4 \mathrm{f}$ denote the shoreline change categories used in this paper.

between 0 and $1 \mathrm{~m}$, coastal slope between 0.04 and $0.07 \%$ and geomorphic setting of category 5 (high vulnerability).

[24] The posterior probability of shoreline change under other input scenarios is shown in Figure 5. Figures 5a-5e show results where each category of sea level rise is specified as the only input. In general, the posterior probability of erosion increases as the rate of sea level rise increases. For the lowest two sea level rise categories, the probabilities of erosion are approximately $30 \%$ but increase to $56 \%$ and $57 \%$ for the highest two sea level rise categories. The posterior probability of a stable shoreline change rate decreases from 34 to $43 \%$ for the two lowest sea level rise categories, respectively, to $22 \%$ or less for the three highest sea level rise categories. In all cases, the posterior probability of accretion is $40 \%$ or less for each sea level rise category.

[25] Other input variables in the BN can be constrained as well in an attempt to maximize the certainty of an outcome. Figures $5 \mathrm{f}-5 \mathrm{j}$ illustrate how selecting more specific conditions can result in higher probability predictions. Here the results of the same sea level cases shown in the left column, but all of the input variables are constrained so there is a $100 \%$ probability of the mean wave height between 0.85 and $1.05 \mathrm{~m}$, a tidal range between 0 and $1 \mathrm{~m}$, a slope between 0.04 and $0.07 \%$, and a geomorphic classification of 4 (geomorphic risk classifications defined in section 2.2). The results show that the shoreline change posterior probabilities are near $100 \%$ for the highest three sea level rise categories (Figures $5 \mathrm{~h}, 5 \mathrm{i}$, and $5 \mathrm{j}$ ). For a relative sea level rise rate between 2.5 and $2.95 \mathrm{~mm} / \mathrm{yr}$, there is approximately $82 \%$ posterior probability of a stable shoreline change rate and a low posterior probability of erosion (18\%) (Figure 5h). For the two highest relative sea level rise scenarios, there is nearly $100 \%$ probability of erosion for both cases (Figures $5 \mathrm{i}$ and $5 \mathrm{j}$ ). For cases where the rate of sea level rise is low, a high level of uncertainty persists (Figures $5 \mathrm{f}$ and $5 \mathrm{~g}$ ), where none of the shoreline change rate probabilities exceed $40 \%$. This result also illustrates that for the specific choice of the other inputs (waves, tides, and geomorphology) there is very little shoreline change rate sensitivity at low sea level rise rates.

\subsection{Bayesian Network Skill Assessment}

[26] We evaluate whether the network can reproduce the shoreline change observations used to train the model to test the utility of the BN. For example, if there are no systematic correlations between the network's variables, then the best prediction for shoreline change is the prior prediction shown in Figure 3. This result is apparent from equation (3), when the first term in the numerator does not depend on the shoreline change rate, $R$.

[27] There are several possible approaches to assessing prediction skill when the prediction explicitly includes uncertainty. Generally, we wish to determine whether predictions are close to the observations with respect to the predicted uncertainty. Established metrics for this task include the Brier skill score [Brier, 1950] or, nearly equivalently, evaluating a log likelihood ratio [Weigend, 1994]. Both of these approaches are useful primarily for evaluating

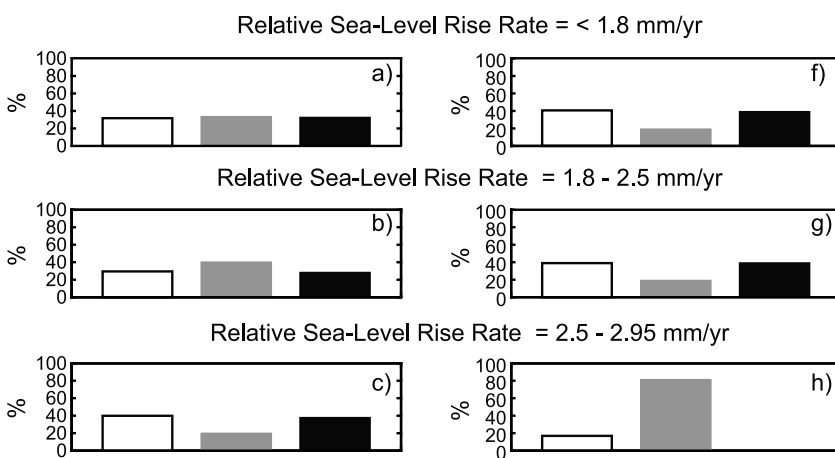

Relative Sea-Level Rise Rate = $2.95-3.15 \mathrm{~mm} / \mathrm{yr}$



Relative Sea-Level Rise Rate $=3.16-4.1 \mathrm{~mm} / \mathrm{yr}$

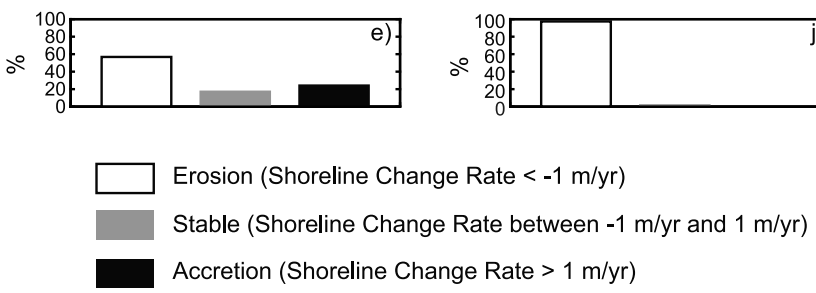

Figure 5. Posterior probability of shoreline change for each relative sea level rise rate category. (a-e) Shoreline change posterior probabilities for cases where only the rate of relative sea level rise is constrained (as in Figure 3, which corresponds to Figure 5e). (f-j) Shoreline change posterior probabilities where there is a specified $100 \%$ probability that the mean wave height is between 0.85 and $1.05 \mathrm{~m}$, a tidal range is between 0 and $1 \mathrm{~m}$, a slope is between $0.04 \%$ and $0.07 \%$, and there is a geomorphic setting of 4 (see Table 1). 


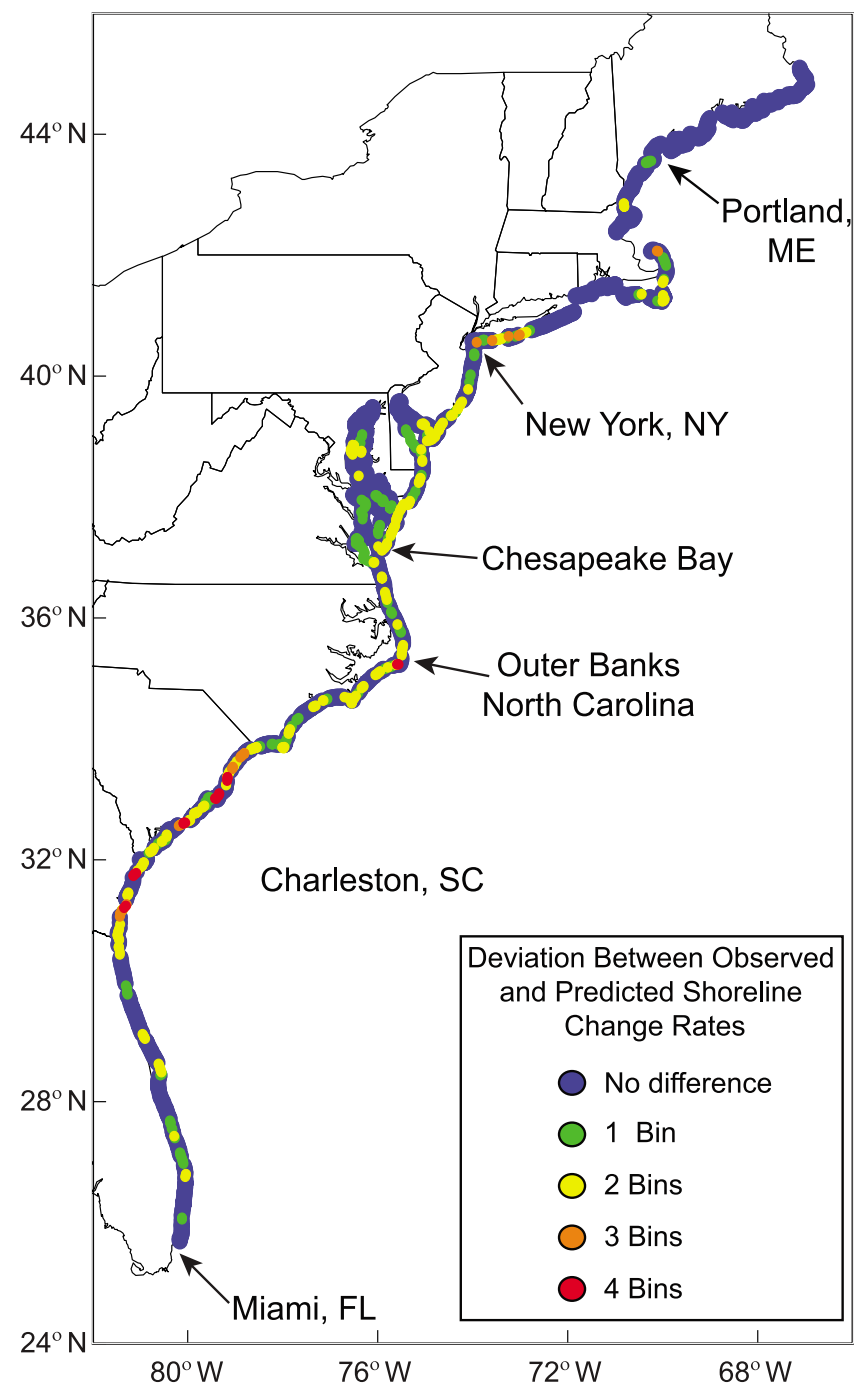

Figure 6. Map of the U.S. Atlantic coast showing the difference (expressed in the number of rate-of-change bins as described in text) between observed and predicted shoreline change rates. Because of the high data density, larger markers indicating no difference (blue) are plotted beneath those indicating a difference between predictions and observations.

the relative skill of several models, where a model that is both accurate (predictions are close to the observations) and precise (low uncertainty) receives a high score and models that are inaccurate, imprecise, or both receive lower scores. Similar approaches based on the Brier skill or log likelihood scores (which are themselves closely related) have been used previously for this purpose [e.g., Atger, 2004; Marcot et al., 2006; Barillec and Cornford, 2009]. In this paper, we present both Brier skill and log likelihood scores.

[28] We compare the predictions from the $\mathrm{BN}$ to observed shoreline change rates for the initial part of our skill assessment. The predictions were produced by using the $\mathrm{BN}$ to generate posterior probability density functions (pdf) for the conditions at specific locations included in our data set. Using the output pdfs, we selected the bin center of the shoreline change rate pdf with the maximum probability, which is defined as

$$
R_{\max }=\arg \max \left(p\left(R_{i}\right)\right),
$$

where $R_{\max }$ can take on values of $-13.5,-1.5,0,1.5$, or $16 \mathrm{~m} / \mathrm{yr}$, and $\operatorname{argmax}(p[x])$ returns the value $x$ that maximizes the discrete probability of the output pdf. These five values correspond to the centers of the five shoreline change rate bins specified in the $\mathrm{BN}$ (see Figure $3 \mathrm{f}$ ).

[29] Figure 6 shows a comparison of observed and predicted shoreline change outcomes $\left(R_{\max }\right)$ computed for each geographic location in the data set. Seventy-one percent of the observed rates occur in the same bin as the corresponding predicted rate with the highest posterior probability $R_{\max }$, which indicates a successful prediction (Figure 6, blue circles). Thirteen percent of the predictions fall in an adjacent bin, and the remaining $16 \%$ differ by two or more bins.

[30] We also evaluate how many of the shoreline change rates in the THK99 data set were predicted successfully with $R_{\max }$ probabilities equal to or exceeding 0.67 and 0.9 to demonstrate how results can be translated into established terminology. These probabilities correspond to the likely or very likely definitions of likelihood used by the IPCC and U.S. Climate Change Science Program [Solomon et al., 2007; Titus et al., 2009], respectively. For $P \geq 0.67$, there are 1303 data points. The most probable predicted shoreline change rate bin also contains the corresponding input shoreline change observation for 1150 data points ( $48 \%$ of the data). For $P \geq 0.9$, there are 787 data points. The observations occurred in the same bins as the corresponding predictions for 769 data points ( $32 \%$ of the data). Thus, in established likelihood terms nearly one half of the BN predicted outcome probabilities are high enough to be categorized as likely, and one third are high enough to be designated as very likely.

\subsubsection{Brier Skill}

[31] The Brier skill score [Brier, 1950], here modified so that a perfect score equals one and imperfect scores are less than one, is

$$
B=1-\frac{1}{N} \sum_{i} \sum_{j}\left\{p_{i}\left(R_{j}\right)-\delta\left(R_{j}, O_{i}\right)\right\}^{2},
$$

where $p_{i}\left(R_{j}\right)$ denotes the predicted probability at the $i$ th shoreline location of the $j$ th shoreline change outcome (out of the five possible binned outcomes) and $\delta\left(R_{i}, O_{i}\right)$ is the occurrence or "hit" of the observation, which, following Brier [1950] and others, is equal to one if the data falls in the range of the $j$ th outcome and is zero otherwise. The number of geographic locations is given by $N$. The Brier skill score measures the nearness of the predicted probabilities to the observed occurrence, averaged over all possible outcomes. Here, a perfect Brier score of 1 results if all of the predictions have $100 \%$ certainty in the range that matches the data.

[32] Overall, the Brier skill score for the most probable predicted shoreline change rates is 0.77 (Table 3). To understand how the skill score varies by the type of shoreline setting, we evaluate the skill scores by geomorphic setting. The highest skill scores are observed for settings with low vulnerability ( 1 and 2$)$, where the scores are nearly 1 . Geo- 
Table 3. Brier Skill Scores for Shoreline Change Rate Predictions Categorized for the Entire Data Set by Geomorphic Setting

\begin{tabular}{lcc}
\hline \multicolumn{1}{c}{ Category } & $N$ & Score \\
\hline All predictions & 2378 & 0.77 \\
Geomorphic setting 1 & 318 & 0.99 \\
Geomorphic setting 2 & 54 & 0.96 \\
Geomorphic setting 3 & 234 & 0.77 \\
Geomorphic setting 4 & 414 & 0.77 \\
Geomorphic setting 5 & 1358 & 0.71 \\
\hline
\end{tabular}

morphic setting 1 (very low vulnerability) corresponds to steep, rocky coast where shoreline change is reliably predicted and observed to be stable. Lower skill but favorable scores are observed for moderate- and higher-vulnerability settings (3-5).

\subsubsection{Log Likelihood Ratio}

[33] To measure the performance of the $\mathrm{BN}$ predictions relative to an alternative model also consisting of the prior probability, we compute the log likelihood ratio:

$$
\mathrm{L} R_{i}=\log \left\{p_{i}\left(O_{i}\right)\right\}-\log \left\{p_{i}^{\text {prior }}\left(O_{i}\right)\right\},
$$

where $p_{i}\left(O_{i}\right)$ is the probabilistic prediction evaluated for the outcome that matches the observation and $p_{i}^{\text {prior }}\left(O_{i}\right)$ denotes the corresponding prior probability [Weigend, 1994]. A positive log likelihood ratio results if the likelihood of the updated prediction increases over the prior, indicating that the update is either more accurate (the distribution corresponds to the observation) or more certain (a narrower distribution) or both more accurate and more certain (Figure 7). A ratio exceeding one indicates a significant improvement in prediction. Log likelihood ratios less than zero indicate that the predicted outcome is worse than its prior probability. This can result from a case where the predicted outcome has a high probability but differs from actual outcome (e.g., incorrectly predicts erosion where stability was observed). Finally, the $\log$ likelihood ratios can be summed over all of the geographic locations $(N=2378)$ to give an overall score:

$$
\overline{\mathrm{L} R}=\sum_{i} \log \left\{p_{i}\left(O_{i}\right)\right\}-\sum_{i} \log \left\{p_{i}^{\text {prior }}\left(O_{i}\right)\right\},
$$

For the BN used here, the sum of the log likelihood ratios is 619 and indicates that the BN predictions are substantially better than the prior probability. Eighty-six percent of the individual $\log$ likelihood ratios were greater than zero but less than 1 . The remaining $14 \%$ of the ratios were all less than zero.

[34] We also compute the sum of the log likelihood ratio for a number of different cases by varying the number of input variables used in the BN. Figure 8 illustrates how the sum of the log likelihood ratio varies depending on the number and type of variables chosen. In general, the sum of the log likelihood ratio increases with the number of parameters used in the network. The results of this comparison show that all of the variables need to be included in the network to achieve the highest log likelihood ratio sum. This analysis shows that sea level rise is the most important variable for predicting shoreline erosion probabilities. And, for any choice of a limited set of input variables, those where sea level rise was specified resulted in the highest score. For one case, where the
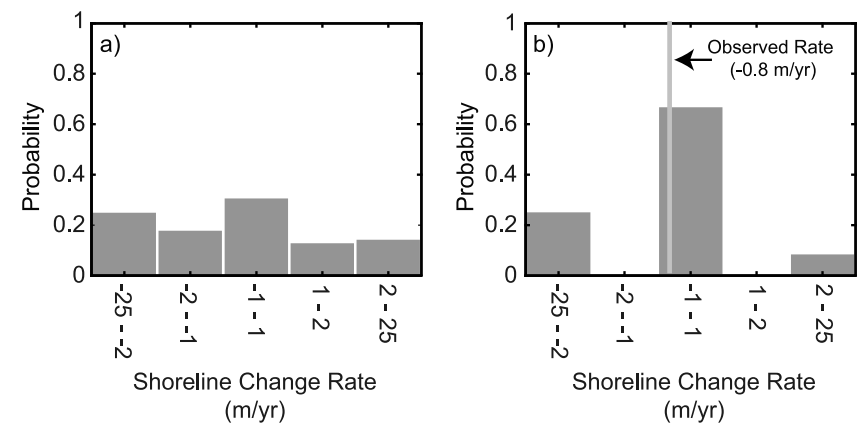

Figure 7. Comparison of (a) prior and (b) posterior probability density functions for shoreline change rates calculated for our BN. The posterior (or updated) case (Figure 7b) corresponds to the probability of shoreline change where the predicted rate coincides with the observed rate and thus results in a more accurate and more certain prediction. For this case, the $\log$ likelihood ratio is 0.39 , indicating that the predicted posterior probability of shoreline change is an improvement over the prior probability.

rate of sea level rise, wave height, tide range, and coastal slope are specified (i.e., we exclude geomorphic setting), the sum for these four variables is close to the sum of the log likelihood ratio calculated for the case where all five variables are specified. The other variables can be ranked by their impact on the likelihood ratio. However, it is clear that the joint correlations that are used to relate the variables to each other can combine multiple inputs to yield predictions that are far better than the sum of the individual contributions.

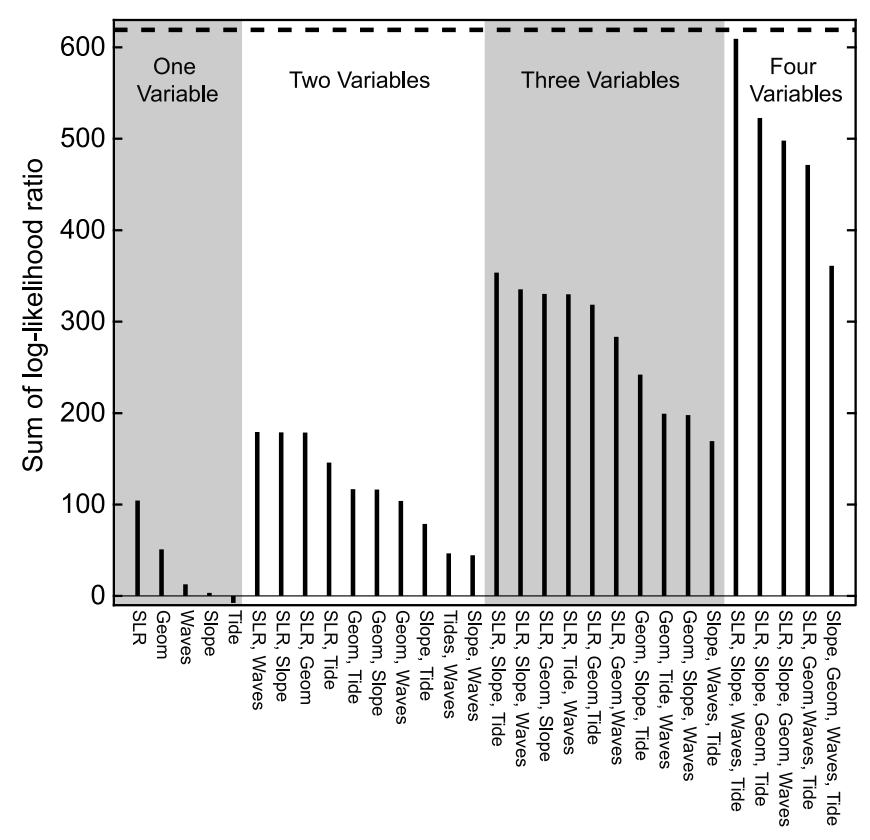

Figure 8. Bar graph of the sum of the log likelihood ratio calculated for all combinations where 1-4 variables are chosen. The dashed line depicts the sum of this ratio (619) where all variables are specified. 

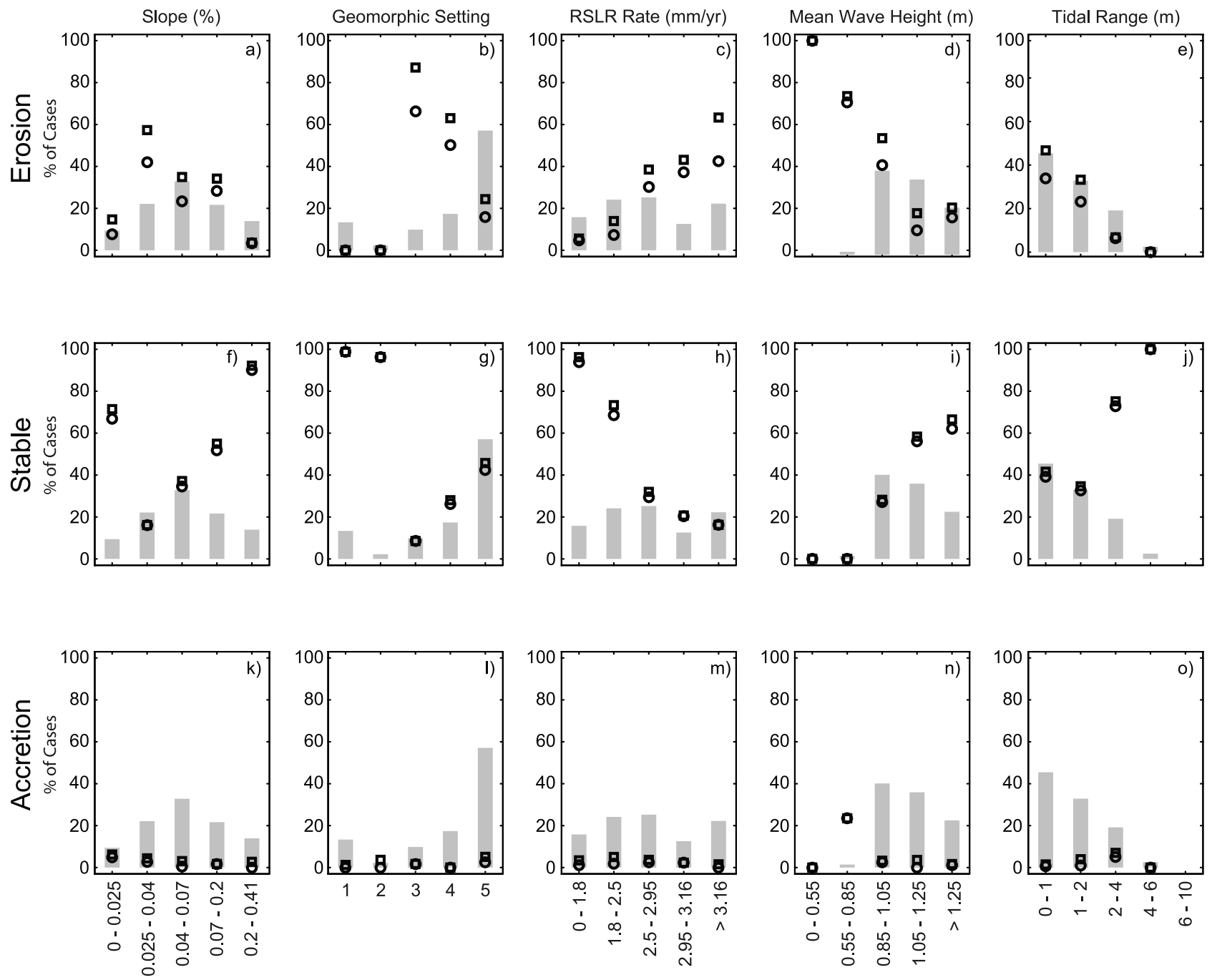

Figure 9. $(\mathrm{a}-\mathrm{o}) \mathrm{Graphs}$ showing the percentage of cases where the predicted most probable shoreline change rate falls in the same bin as the observations (circles) or falls within one bin of the observations (squares). Each row corresponds to the three classes of shoreline change outcomes, and each column corresponds to one of the five input variables. The ordinate value of each marker specifies the percent of each variable category for that shoreline change outcome, divided by the total number of that variable category in the data set and multiplied by 100 . Grey bars show the percent of each category with respect to the entire data set.

\subsubsection{Characteristics of Successful Predictions}

[35] The accuracy of the BN over a large number of prediction scenarios is presented in Figure 9, which shows where $R_{\max }$ (equation (4)) matched observed shoreline change rates or where it matched within one bin. The results in Figure 9 are displayed in three rows according to the predicted shoreline change rate. In each graph, the percentage of successful shoreline change predictions for each of the variable ranges is shown. The percentage is normalized by the overall number of cases for that category in the data set. For example, in Figure $9 b$ the point farthest to the right specifies the number of correct erosion predictions where the geomorphic settings is 5 divided by the total number of cases where the geomorphic setting is 5 in the entire data set (and then multiplied by 100 to express as a percentage). Where erosion or stable shoreline change rates (Figures $9 \mathrm{a}-9 \mathrm{e}$ and $9 \mathrm{f}-9 \mathrm{j}$, respectively) are successfully predicted, distinct differences exist in the input variables. Figures $9 \mathrm{a}-9 \mathrm{e}$ indicate that erosion is predicted for a high percentage of cases where the rate of sea level rise is high, geomorphic settings of moderate-tohigh vulnerability, and tidal range is low. Figure 9d shows that although a high percentage of cases indicate that erosion is predicted in low wave height environments, there are relatively few observations comprising these environments in the data set, indicated by a histogram in grey. Instead, erosion predictions tend to occur in moderate wave-height environments, which are abundant in the data set. In contrast, Figures $9 f-9 j$ show that stable rates of shoreline change are predicted where low-vulnerability geomorphic settings, lower rates of sea level rise, high wave height, and high tidal range environments are present. Last, Figures $9 \mathrm{k}-9 \mathrm{o}$ suggest that accretion is not predicted consistently for any specific set of conditions. 

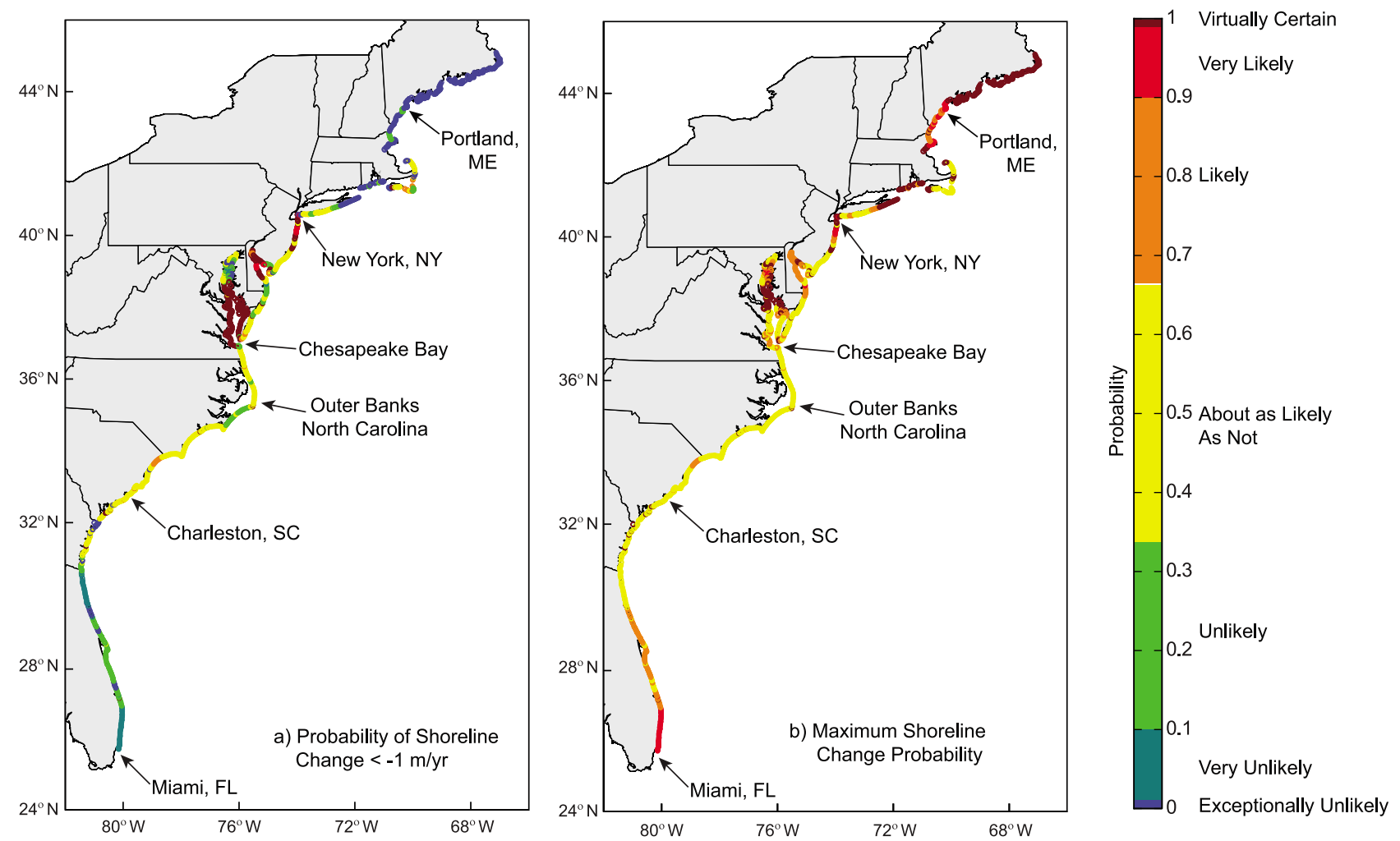

Figure 10. Maps of the U.S. Atlantic coast showing (a) the posterior probability of shoreline change $<-1 \mathrm{~m} / \mathrm{yr}$ and (b) the maximum posterior probability for each location. The probabilities are color coded and labeled using IPCC likelihood terminology.

\subsection{Mapping Outcomes}

[36] So far, the results have not referenced spatial locations (or time periods) where input data or sea level rise projections would be used to constrain the BN. Because data used in the hindcast evaluation are derived from specific locations and represent historical averages, the $\mathrm{BN}$ results can be shown in their geographic context (Figure 10). Posterior probabilities for different shoreline change outcomes are shown using established IPCC terminology to describe the level of likelihood or uncertainty as noted above (section 3.2.1). Figure 10a shows the probability of shoreline change $<-1 \mathrm{~m} / \mathrm{yr}$ at each location. This indicates the probability of moderate to severe erosion. Figure $10 \mathrm{~b}$ shows the probability of the most likely outcome and can be used to identify areas where there is a high degree of confidence in any outcome prediction, as well as locations where there is a greater degree of uncertainty. This information can be useful for identifying where the BN needs to include more or better information to represent these settings. Alternatively, these regions may also indicate where scientific understanding of these coastal settings needs improvement.

\section{Discussion}

\subsection{Implications}

[37] The results of our study confirm that a BN trained with a historical data set can be used to learn quantitative relationships between the long-term shoreline change rate and sea level rise while including a range of other factors describing physical characteristics of a particular geographic location. Results indicate that the $\mathrm{BN}$ provides successful predictions for $71 \%$ of the cases represented in the input data set. The other skill metrics, the Brier score and the log likelihood ratio, also indicate that the BN performs well. The examples in section 3.2 show that where only rates of sea level rise are specified, posterior probabilities of shoreline change increase with higher rates of sea level rise. In addition, examining the log likelihood ratio for different numbers and combinations of input variables illustrates the importance of the sea level rise variable (section 3.3 and Figure 8). This clarifies the value of the sea level rise variable in predicting future shoreline erosion rates.

[38] When examined according to geomorphic setting, Brier scores indicate that the $\mathrm{BN}$ performs well for settings 1 , 2 , and 3 and less so for 4 and 5 but still results in predictions that are better than the prior probability. We presume that the lower skill scores for predictions in settings 4 and 5 stem from a combination of factors, including (1) the relatively high number of data points in the data set (414 and 1358, respectively) that represent a range of physical conditions along the U.S. Atlantic coast resulting in increased scatter in the input data and lowering the score and (2) the influence of erosion management measures (beach nourishment, jetties, groins, and seawalls, which are abundant on the U.S. East Coast) on long-term shoreline change rates. These measures have been 
active over much of the U.S. East Coast over the last half century or more [Valverde et al., 1999; Nordstrom, 2000].

[39] The characteristics of successfully predicted cases from our input data set show that erosion is predicted (shoreline change rate $<-1 \mathrm{~m} / \mathrm{yr}$ ) for cases where there are higher rates of sea level rise, and tend to occur in moderateto-high vulnerability geomorphic settings (setting category 3-4). Stable shoreline settings $(-1 \mathrm{~m} / \mathrm{yr}<$ shoreline change rate $<1 \mathrm{~m} / \mathrm{yr}$ ), tend to occur where sea level rise rates are lower, and in lower-vulnerability geomorphic settings (see Figure 9). We are unable to identify clearly the characteristics of locations where accretion (shoreline change rate $>1 \mathrm{~m} / \mathrm{yr}$ ) is the most probable outcome. There are a few specific cases with high certainties of accretion found by trial and error use of the BN to select specific physical settings (e.g., sea level rise rate $=0-1.8$ or $2.5-2.95 \mathrm{~mm} / \mathrm{yr}$, mean wave height $=$ $1.05-1.25$ or $>1.25 \mathrm{~m}$, tidal range $=0-1$ or $1-2 \mathrm{~m}$, slope $=$ $0.07-0.2 \%$, and geomorphic setting $=5$ ). But in evaluating all of the cases present in our data set, we cannot identify robustly the specific characteristics that distinguish settings where accretion is most probable in comparison to settings where erosion or stability are predicted (see Figure 9). It is likely that this shortcoming is related to the relative paucity of shoreline change observations indicating accretion (Table 2), which may influence the ability of the $\mathrm{BN}$ to predict this outcome with a high degree of certainty.

[40] There also appears to be a spatial influence on our results. For example, geomorphic setting 1, which is confined mostly to a specific geographic region with relatively uniform physical characteristics (e.g., coast of northern Massachusetts to Maine), has high skill scores relative to geomorphic setting 5 , which occurs in a more diverse range of locations along the U.S. Atlantic coast. These geographic differences are used to predictive advantage in the BN using very little information about geologic or oceanographic processes. That is, if a coast is bounded by high rocky cliffs, the erosion rate hardly depends on any other information and uncertainties (such as future sea level rise rate) have no impact on the prediction. The regions where predictions are less confident are objectively identified and describe a need to add both more observations from similar settings at other locations and/or other variables to improve the predictive capability of this BN.

[41] Given the need for effective means of decision support to parameterize climate change impacts such as sea level rise [e.g., Tribbia and Moser, 2008; NRC, 2009; Thieler et al., 2009], BNs will be a useful medium to involve both scientists and decision makers in the development of new decision support tools [McCann et al., 2006; Henriksen et al., 2007; Ticehurst et al., 2007; Martin de Santa Olalla et al., 2007]. Predictions can be mapped to provide a spatial representation of the level of confidence in a specific outcome. As illustrated here, the outcome probabilities can be translated into established likelihood terms such as those used in recent IPCC climate change assessments (see sections 3.3 and 3.4 and Figures 10a and 10b), which is a vital need in communicating potential future climate change impacts. Recent application of the BN approach to environmental management indicates that engagement of scientists, users (decision makers or managers), and stakeholders is an important aspect of the development of a BN for specific problems [Henriksen et al.,
2007; Marcot et al., 2006; Nyberg et al., 2006]. Increased and sustained interactions between scientists, managers and stakeholders can improve climate change decision support [NRC, 2009].

\subsection{Opportunities for Improved Predictions}

[42] The BN described here can be viewed as a flexible and adaptable starting point for addressing sea level rise and shoreline change. This kind of application can also provide a structured framework to identify and evaluate new areas for scientific inquiry. One of the strengths of approaching a problem using a $\mathrm{BN}$ is that it can be updated easily with new data and additional variables as knowledge improves and information becomes available [Marcot et al., 2006; Nyberg et al., 2006]. Consequently, BN development is viewed commonly as an ongoing process. In this section we review several aspects of our work that may lead to improved BN performance.

[43] Our data set could be improved by incorporating more robust observations. The THK99 data rely on shoreline change observations compiled by Dolan et al. [1985] that contain rates calculated using different methods and time spans. Since then, a number of researchers have explored more rigorous statistical methods for calculating shoreline change rates [Dolan et al., 1991; Crowell et al., 1997; Ruggiero and List, 2009], and developed more consistent and modern data [e.g., Morton and Miller, 2005; Morton et al., 2004; Hapke et al., 2006]. Likewise, data representing a larger spatial domain may increase the representation of specific scenarios and improve the ability to predict outcomes for a wider range of conditions.

[44] Adding other variables may improve the ability to provide high-probability predictions. One example is a variable indicating the presence of an engineering structure such as seawall, jetty, or groin, or noting the proximity to a tidal inlet. These factors have been shown to have an influence on shoreline changes in some locations (e.g., Ocean City, Maryland, jetties [Leatherman, 1979, Dolan et al., 1980]; Sandy Hook, New Jersey, shore protection structures [Allen, 1981; Nordstrom, 2000]; and U.S. East Coast inlets [Galgano, 1998]). As noted previously, coastal engineering structures such as these may account for some of the variability exhibited by shoreline change rates from geomorphic setting 5. Other variables, such as dune height and beach or barrier island width, that provide a more complete description of barrier island geometry and how it changes over time could be included. For settings like barrier islands, decreases in dune height or barrier width may be important vulnerability indicators [e.g., Leatherman, 1979; Sallenger, 2000; Stockdon et al., 2007]. To improve the ability of the $\mathrm{BN}$ to make better predictions of cases where accretion occurs, it is important to evaluate and include other variables to describe the accretion scenario. This might include information regarding coastal sediment budgets [Komar, 1996; Schwab et al. 2000; Rosati, 2005].

[45] In the future, rates of sea level rise and shoreline change may increase to states that do not exist in the historical data set on which our $\mathrm{BN}$ is based. Modifications could be made to address this. Our data set could be expanded to include settings such as the U.S. Gulf of Mexico coast that have experienced relatively high rates of sea level rise and 
coastal change. Expanding the data set to include cases where geomorphic thresholds have been crossed (e.g., barrier island stability evolving to barrier island migration or fragmentation) may also be important for higher rates of relative sea level rise [Titus et al., 2009]. While there are some available observations of this type of coastal evolution (e.g., Louisiana barrier islands [Penland et al., 1985; Sallenger et al., 2009]), they are not widespread in a range of coastal settings. In this situation, geometric models of coastal evolution could be employed (e.g., STM or GEOMBEST [Cowell et al., 1995; 2006; Stolper et al., 2005]) to augment observational data sets and provide information regarding extreme scenarios. Alternatively, model results could be used to test $\mathrm{BN}$ performance for controlled scenarios or used to compare with BN-based predictions.

[46] This network can also be expanded beyond shoreline settings and integrate data from adjacent environments such as coastal wetland ecosystems that will also be affected by sea level rise. The flexibility of the BN framework allows integration with other information, such as variables that contribute to wetland survival [Reed et al., 2008; Kirwan and Guntenspergen, 2010; Kirwan et al., 2010], impacts to groundwater systems [Masterson and Garabedian, 2007], or coastal habitat and species impacts [Shellenbarger Jones et al., 2009]. This approach can also be linked to similar frameworks for storm hazards [Stockdon et al., 2007] to provide a more comprehensive assessment of risks to coastal settings.

\section{Conclusions}

[47] We demonstrate here that Bayesian networks can provide probabilistic predictions of shoreline change rates using readily available data on driving forces (rate of sea level rise, wave height, tidal range) and boundary conditions (geomorphic setting, coastal slope). The probability of shoreline change increases with the rate of sea level rise. This trend is especially clear for some cases where specific values of each of the input variables are chosen. Evaluation of each specific case in our data set shows that the Bayesian network correctly predicts shoreline change rates for $71 \%$ of the cases.

[48] Brier skill and log likelihood ratio scores $(0.77$ and 619 , respectively) indicate that the $\mathrm{BN}$ provides predictions that are better than the prior behavior. The log likelihood ratios show that the $\mathrm{BN}$ predictions are substantially better than the prior probability. Eighty-six percent of the individual log likelihood ratios are greater than zero, indicating a shoreline change prediction that is better than the prior probability. Examining the influence of different combinations of input variables demonstrates that those where sea level rise is specified results in the highest log likelihood scores.

[49] Examining cases where the BN reproduced observed shoreline change rates indicates that there is a relationship between the rate of relative sea level rise and shoreline change. Shoreline change rates indicating erosion result for cases where the rate of relative sea level rise is high and moderate-to-high vulnerability geomorphic settings occur. Stable shoreline change rates occur mainly for low rates of relative sea level rise and most often for low-vulnerability geomorphic settings. Accretion is not well predicted for any specific set of conditions.

[50] Our evaluation also shows that the BN approach provides a means for quantifying and communicating the level of uncertainty of an outcome. Here, we show that the results can be mapped and displayed using the likelihood terms adopted by the IPCC for recent climate change assessments.

[51] Bayesian networks are a useful means to integrate coastal hazards data to develop predictive tools to inform the decision making process. The flexibility of the Bayesian approach allows the integration of both quantitative and qualitative data. This attribute will be useful in developing more comprehensive assessments of climate change impacts.

[52] Acknowledgments. Funding for this work was provided by the USGS Coastal and Marine Geology and Global Change Research programs. We thank Chris Sherwood of the USGS Woods Hole Coastal and Marine Science Center and Tom Smith of the USGS Southeast Ecological Science Center for reviews of an early version of the paper. We also thank three anonymous reviewers and the associate editor for providing valuable suggestions and critiques of this paper. Any use of trade, product, or firm names is for descriptive purposes only and does not imply endorsement by the U.S. government.

\section{References}

Abuodha, P. A. O., and C. D. Woodroffe (2010), Assessing vulnerability to sea-level rise using a coastal sensitivity index, J. Coast. Conserv., 14, 189-205, doi:10.1007/s11852-010-0097-0.

Allen, J. R. (1981), Beach erosion as a function of variations in the sediment budget, Sandy Hook, New Jersey, USA, Earth Surf. Processes Landforms, 6, 139-150.

Aspinall, W. P., G. Woo, B. Voight, and P. J. Baxter (2003), Evidencebased volcanology: Application to eruption crises, J. Volcanol. Geotherm. Res., 128, 273-285, doi:10.1016/S0377-0273(03)00260-9.

Atger, F. (2004), Relative impact of model quality and ensemble deficiencies on the performance of ensemble based probabilistic forecasts evaluated through the Brier score, Nonlinear Processes Geophys., 11, 399-409, doi:10.5194/npg-11-399-2004

Bamber, J. L., R. E. M. Riva, B. L. A. Vermeersen, and A. M. LeBrocq (2009), Reassessment of the potential sea-level rise from the collapse of the West Antarctic ice sheet, Science, 324, 901-903, doi:10.1126/ science. 1169335 .

Barillec, R., and D. Cornford (2009), Data assimilation for precipitation nowcasting using Bayesian inference, Adv. Water Resour., 32, 1050-1065, doi:10.1016/j.advwatres.2008.09.004.

Bayes, T. (1763), An essay towards solving a problem in the doctrine of chances, Philos. Trans. R. Soc. London, 53, 370-418. [Reprinted in Biometrika, 45, 296-315, 1958, doi:10.1093/biomet/45.3-4.296.]

Berger, J. O. (2000), Bayesian analysis: A look at today and thoughts of tomorrow, J. Am. Stat. Assoc., 95, 1269-1276, doi:10.2307/2669768.

Borsuk, M. E., C. A. Stow, and K. H. Reckhow (2004), A Bayesian network of eutrophication models for synthesis, prediction, and uncertainty analysis, Ecol. Modell., 173, 219-239, doi:10.1016/j.ecolmodel.2003.08. 020.

Brier, W. G. (1950), Verification of forecasts expressed in terms of probability, Mon. Weather Rev., 78, 1-3, doi:10.1175/1520-0493(1950)078< 0001:VOFEIT>2.0.CO;2.

Bruun, P. (1962), Sea-level rise as a cause of shore erosion, J. Waterw. Harbors Coastal Eng. Div. Am. Soc. Civ. Eng., 88, 117-130.

Cahoon, D. R., D. J. Reed, A. S. Kolker, M. M. Brinson, J. C. Stevenson, S. Riggs, R. Christian, E. Reyes, C. Voss, and D. Kunz (2009), Coastal wetland sustainability, in Coastal Sensitivity to Sea-Level Rise: A Focus on the Mid-Atlantic Region, pp. 57-72, U.S. Clim. Change Sci. Program, Washington, D. C.

Carter, R. W. G., and C. D. Woodroffe (1994), Coastal evolution: An introduction, in Coastal Evolution: Late Quaternary Shoreline Morphodynamics, edited by R. W. G. Carter and C. D. Woodroffe, pp. 1-31, Cambridge Univ. Press, Cambridge, U. K.

Castelletti, A., and R. Soncini-Sessa (2007a), Bayesian networks and participatory modeling in water resource management, Environ. Model. Softw., 22, 1075-1088, doi:10.1016/j.envsoft.2006.06.003. 
Castelletti, A., and R. Soncini-Sessa (2007b), Coupling real-time control and socio economic issues in participatory river basin planning, Environ. Model. Softw., 22, 1114-1128, doi:10.1016/j.envsoft.2006.05.018.

Cooper, J. A. G., and O. H. Pilkey (2004), Sea-level rise and shoreline retreat: Time to abandon the Bruun Rule, Global Planet. Change, 43, 157-171, doi:10.1016/j.gloplacha.2004.07.001.

Cowell, R. (1999), Introduction to inference for Bayesian networks, in Learning in Graphical Models, edited by M. I. Jordan, pp. 9-26, MIT Press, Cambridge, Mass.

Cowell, P. J., and T. Q. Zeng (2003), Integrating uncertainty theories with GIS for modeling coastal hazards of climate change, Mar. Geod., 26, 5-18, doi:10.1080/01490410306700.

Cowell, P. J., P. S. Roy, and R. A. Jones (1995), Simulation of large-scale coastal change using a morphological behavior model, Mar. Geol., 126, 45-61, doi:10.1016/0025-3227(95)00065-7.

Cowell, P. J., B. G. Thom, R. A. Jones, C. H. Everts, and D. Simanovic (2006), Management of uncertainty in predicting climate-change impacts on beaches, J. Coastal Res., 22, 232-245, doi:10.2112/05A-0018.1.

Crowell, M., B. C. Douglas, and S. P. Leatherman (1997), On forecasting future U.S. shoreline positions: A test of algorithms, J. Coastal Res., 13 , $1245-1255$.

Dolan, R., and J. Peatross (1992), Data supplement to the U.S. Geological Survey 1:2,000,000-scale map of shoreline erosion and accretion of the mid-Atlantic coast, U.S. Geol. Surv. Open File Rep., 92-377, 116 pp.

Dolan, R., H. F. Lins, and J. Stewart (1980), Geographical Analysis of Fenwick Island, Maryland, a Middle Atlantic Coast Barrier Island, U.S. Geol. Surv. Prof. Pap., 1177-A, 24 pp.

Dolan, R., F. Anders, and S. Kimball (1985), Coastal erosion and accretion, in National Atlas of the United States of America, 1 sheet, U.S. Geol. Surv., Reston, Va.

Dolan, R., S. Trossbach, and M. Buckley (1990), New shoreline erosion data for the mid-Atlantic coast, J. Coastal Res., 6, 471-477.

Dolan, R., M. S. Fenster, and S. J. Holme (1991), Temporal analysis of shoreline recession and accretion, J. Coastal Res., 7(3), 723-744.

Douglas, B. C., (2001), Sea level change in the era of the recording tide gauges, in Sea Level Rise: History and Consequences, Int. Geophys. Ser., vol. 75., edited by B. C. Douglas, M. S. Kearney, and S. P. Leatherman, pp 37-64, Academic, San Diego, Calif.

FitzGerald, D. M., M. S. Fenster, B. Argow, and I. V. Buynevich (2008), Coastal impacts due to sea-level rise, Annu. Rev. Earth Planet. Sci., 36 , 601-647, doi:10.1146/annurev.earth.35.031306.140139.

Galgano, F. A. (1998), Geomorphic analysis of modes of shoreline behavior and the influence of tidal inlets on coastal configuration, U.S. East Coast, Ph.D. thesis, 464 pp., Univ. of Md., College Park.

Gelman, A., J. B. Carlin, H. S. Stern, and D. B. Rubin (2004), Bayesian Data Analysis, 2nd ed., Chapman and Hall, New York.

Gesch, D. B. (2009), Analysis of lidar elevation data for improved identification and delineation of lands vulnerable to sea level rise, J. Coastal Res. Spec. Issue, 53, 49-58, doi:10.2112/SI53-006.1.

Gesch, D. B., B. T. Gutierrez, and S. K. Gill (2009), Coastal elevations, in Coastal Sensitivity to Sea-Level Rise: A Focus on the Mid-Atlantic Region, pp. 25-42, U.S. Clim. Change Sci. Program, Washington, D. C.

Gornitz, V. M., and P. Kanciruk (1989), Assessment of global coastal hazards from sea level rise, in Coastal Zone '89: Proceedings of the Sixth Symposium on Coastal and Ocean Management, pp. 1345-1359, Am. Soc. of Civ. Eng., New York.

Gornitz, V., S. Couch, and E. K. Hartig (2001), Impacts of sea level rise in the New York City metropolitan area, Global Planet. Change, 32, 61-88, doi:10.1016/S0921-8181(01)00150-3.

Grinsted, A., J. C. Moore, and S. Jevrejeva (2010), Reconstructing sea level from paleo and projected temperatures, Clim. Dyn., 34, 461-472, doi:10.1007/s00382-008-0507-2.

Gutierrez, B. T., S. J. Williams, and E. R. Thieler (2009), Ocean coasts, in Coastal Sensitivity to Sea-Level Rise: A Focus on the Mid-Atlantic Region, pp. 43-56, U.S. Clim. Change Sci. Program, Washington, D. C.

Hammar-Klose, E. S., and E. R. Thieler (2001), Coastal vulnerability to sea-level rise: A preliminary database for the U.S. Atlantic, Pacific and Gulf of Mexico coasts [CD-ROM], U.S. Geol. Surv. Digital Data Ser., vol. 68, U.S. Geol. Surv., Woods Hole, Mass.

Hapke, C. J., D. Reid, B. M. Richmond, P. Ruggiero, and J. List (2006), National assessment of shoreline change: Part 3, Historical shoreline change and associated land loss along sandy shorelines of the California coast, U.S. Geol. Surv. Open File Rep., 2006-1219, 72 pp.

Hayes, M. O. (1979), Barrier island morphology as a function of tidal and wave regime, in Barrier Islands: From the Gulf of St. Lawrence to the Gulf of Mexico, edited by S. P. Leatherman, pp. 211-236, Academic, San Diego, Calif.
Heckerman, D. (1999), A tutorial on learning with Bayesian networks, in Learning in Graphical Models, edited by M. I. Jordan, pp. 301-354, MIT Press, Cambridge, Mass.

Henriksen, H. J., P. Rasmussen, G. Brandt, D. von Bülow, and F. V. Jensen (2007), Public participation modeling using Bayesian networks in management of groundwater contamination, Environ. Model. Softw., 22, 1101-1113, doi:10.1016/j.envsoft.2006.01.008.

Horton, R., C. Herweijer, C. Rosenzweig, J. Liu, V. Gornitz, and A. C. Ruane (2008), Sea level rise projections for current generation CGCMs based on the semi-empirical method, Geophys. Res. Lett., 35, L02715, doi:10.1029/2007GL032486.

Houghton, J. T., Y. Ding, D. J. Griggs, M. Noguer, P. J. van der Linden, X. Dai, K. Maskell, and C. A. Johnson (Eds.) (2001), Climate Change 2001: The Scientific Basis: Contribution of Working Group I to the Third Assessment Report of the Intergovernmental Panel on Climate Change, Cambridge Univ. Press, Cambridge, U. K.

Hu, A., G. A. Meehl, W. Han, and J. Yin (2009), Transient response of the MOC and climate to potential melting of the Greenland Ice Sheet in the 21 st century, Geophys. Res. Lett., 36, L10707, doi:10.1029/ 2009GL037998.

Hubertz, J. M., E. F. Thompson, and H. V. Wang (1996), Wave Information Studies of U.S. coastlines: Annotated bibliography on coastal and ocean data assimilation, WIS Rep. 36, 46 pp., U.S. Army Eng. Waterw. Exp. Stn., Vicksburg, Miss.

Jensen, F. V., and T. D. Nielsen (2007), Bayesian Networks and Decision Graphs, Springer, New York.

Jevrejeva, S., J. C. Moore, and A. Grinsted (2010), How will sea level respond to changes in natural and anthropogenic forcings by 2100 ?, Geophys. Res. Lett., 37, L07703, doi:10.1029/2010GL042947.

Kana, T. W., J. Michel, M. O. Hayes, and J. R. Jensen (1984), The physical impact of sea level rise in the area of Charleston, South Carolina, in Greenhouse Effect and Sea Level Rise: A Challenge for This Generation, edited by M. C. Barth and J. G. Titus, pp. 105-150, Van Nostrand Reinhol, New York.

Kirwan, M. L., and G. R. Guntenspergen (2010), Influence of tidal range on the stability of coastal marshland, J. Geophys. Res., 115, F02009, doi:10.1029/2009JF001400

Kirwan, M. L., G. R. Guntenspergen, A. D’Alpaos, J. T. Morris, S. M Mudd, and S. Temmerman (2010), Limits on the adaptability of coastal marshes to rising sea level, Geophys. Res. Lett., 37, L23401, doi:10.1029/2010GL045489.

Komar, P. D. (1996), The budget of littoral sediments concepts and applications, Shore Beach, 64(3), 18-26.

Leatherman, S. P. (1979), Migration of Assateague Island, Maryland, by inlet and overwash processes, Geology, 7, 104-107, doi:10.1130/00917613(1979)7<104:MOAIMB $>2.0$. CO;2.

Leatherman, S. P. (1984), Coastal geomorphic responses to sea-level rise: Galveston Bay, Texas, in Greenhouse Effect and Sea Level Rise. A Challenge for This Generation, edited by M. C. Barth and J. G. Titus, pp. 151-178, Van Nostrand Reinhold, New York.

Marcot, B. G., J. D. Steventon, G. D. Sutherland, and R. K. McCann (2006), Guidelines for developing and updating Bayesian belief networks applied to ecological modeling and conservation, Can. J. For. Res., 36, 3063-3074, doi:10.1139/X06-135.

Martin de Santa Olalla, F., A. Dominguez, F. Ortega, A. Artigao, and C. Fabeiro (2007), Bayesian networks in planning a large aquifer in Eastern Mancha, Spain, Environ. Model. Softw., 22, 1089-1100, doi:10.1016/j.envsoft.2006.05.020

Masetti, R., S. Fagherazzi, and A. Montanari (2008), Application of a barrier island translation model to the millenial-scale evolution of Sand Key, Florida, Cont. Shelf Res., 28, 1116-1126, doi:10.1016/j.csr.2008.02.021.

Masterson, J. P., and S. P. Garabedian (2007), Effects of sea-level rise on ground water flow in a coastal aquifer system, Ground Water, 45, 209-217, doi:10.1111/j.1745-6584.2006.00279.x.

May, S. K., W. H. Kimball, N. Grady, and R. Dolan (1982), CEIS: The coastal erosion information system, Shore Beach, 50, 19-26.

May, S. K., R. Dolan, and B. P. Hayden (1983), Erosion of U.S. shorelines, Eos Trans. $A G U, 64(35), 521-523$

McCann, R. K., B. G. Marcot, and R. Ellis (2006), Bayesian belief networks: Applications in ecology and natural resource management, Can. J. For. Res., 36, 3053-3062, doi:10.1139/X06-238.

McGranahan, G., D. Balk, and B. Anderson (2007), The rising tide: Assessing the risks of climate change and human settlements in low elevation coastal zones, Environ. Urban., 19(1), 17-37, doi:10.1177/ 0956247807076960.

McNamara, D. E., and B. T. Werner (2008), Coupled barrier island-resort model: 1. Emergent instabilities induced by strong human-landscape interactions, J. Geophys. Res., 113, F01016, doi:10.1029/2007JF000840. 
Meehl, G. A., et al. (2007), Global climate projections, in Climate Change 2007: The Physical Science Basis: Contribution of Working Group I to the Fourth Assessment Report of the Intergovernmental Panel on Climate, chap. 10, edited by S. D. Solomon et al., Cambridge Univ. Press, Cambridge, U. K.

Milne, G. A., W. R. Gehrels, C. W. Hughes, and M. E. Tamisiea (2009), Identifying the causes of sea-level change, Nat. Geosci., 2, 471-478, doi:10.1038/ngeo544.

Mitrovica, J. X., N. Gomez, and P. U. Clark (2009), The sea-level fingerprint of West Antarctic collapse, Science, 323, 753, doi:10.1126/science.1166510.

Morton, R. A. (2003), An overview of coastal land loss: With emphasis on the southeastern United States, U.S. Geol. Surv. Open File Rep., 03-337.

Morton, R. A., and T. L. Miller (2005), National assessment of shoreline change: Part 2, Historical shoreline change and associated land loss along the U.S. Southeast Atlantic coast, U.S. Geol. Surv. Open File Rep., $2005-$ $1401,35 \mathrm{pp}$.

Morton, R. A., T. L. Miller, and L. J. Moore (2004), National assessment of shoreline change: Part 1, Historical shoreline changes and associated coastal land loss along the U.S. Gulf of Mexico, U.S. Geol. Surv. Open File Rep., 2004-1043, 44 pp.

Mount, N., and T. Stott (2008), A discrete Bayesian network to investigate sediment concentrations in an Alpine proglacial zone, Hydrol. Processes, 22, 3772-3784, doi:10.1002/hyp.6981.

Najjar, R. G., et al. (2000), The potential impacts of climate change on the mid-Atlantic coastal region, Clim. Res., 14, 219-233, doi:10.3354/ cr014219.

National Research Council (NRC) (2009), Informing Decisions in a Changing Climate, 188 pp., Natl. Acad. Press, Washington, D. C.

National Research Council (NRC) (2010), Adapting to the Impacts of Climate Change, 325 pp., Natl. Acad. Press, Washington, D. C.

Nicholls, R. J., P. P. Wong, V. R. Burkett, J. O. Codignotto, J. E. Hay, R. F. McLean, S. Ragoonaden, and C. D. Woodroffe (2007), Coastal systems and low-lying areas, in Climate Change 2007: Impacts, Adaptation and Vulnerability: Contribution of Working Group II to the Fourth Assessment Report of the Intergovernmental Panel on Climate Change, edited by M. L. Parry et al., pp. 315-356, Cambridge Univ. Press, Cambridge, U. K.

Nordstrom, K. F. (2000), Beaches and Dunes of Developed Coasts, Cambridge Univ. Press, New York, doi:10.1017/CBO9780511549519.

Nummedal, D. (1983), Barrier islands, in Handbook of Coastal Processes and Erosion, edited by P. D. Komar, pp. 77-121, CRC Press, Boca Raton, Fla.

Nyberg, J. B., B. G. Marcot, and R. Sulyma (2006), Using Bayesian belief networks in adaptive management, Can. J. For. Res., 36, 3104-3116, doi:10.1139/X06-108.

Peltier, W. R. (1994), Ice age paleotopography, Science, 265, 195-201, doi:10.1126/science.265.5169.195.

Pendleton, E. A., E. R. Thieler, and S. J. Williams (2010), Importance of coastal change variables in determining vulnerability to sea- and lake-level change, J. Coastal Res., 26, 176-183, doi:10.2112/08-1102.1.

Penland, S., J. R. Suter, and R. Boyd (1985), Barrier island arcs along abandoned Mississippi River deltas, Mar. Geol., 63, 197-233, doi:10.1016/ 0025-3227(85)90084-2.

Pfeffer, W. T., J. T. Harper, and S. O'Neel (2008), Kinematic constraints on glacier contributions to $21 \mathrm{st}$-century sea-level rise, Science, 321 , 1340-1343, doi:10.1126/science.1159099.

Pilkey, O. H., and T. W. Davis (1987), An analysis of coastal recession models: North Carolina coast, in Sea-Level Fluctuation and Coastal Evolution, Spec. Publ. Soc. Econ. Paleontol. Mineral., vol. 41, edited by D. Nummedal et al., pp. 59-68, Soc. of Econ. Paleontol. and Mineral., Tulsa, Okla, doi:10.2110/pec.87.41.0059.

Pollino, C. A., O. Woodberry, A. Nicholson, K. Korb, and B. T. Hart (2007), Parameterization and evaluation of a Bayesian network for use in an ecological risk assessment, Environ. Model. Softw., 22, 1140-1152, doi:10.1016/j.envsoft.2006.03.006.

Rahmstorf, S. (2007), A semi-empirical approach to projecting future sealevel rise, Science, 315, 368-370, doi:10.1126/science.1135456.

Ranasinghe, R., and M. J. F. Stive (2009), Rising seas and retreating coastalines, Clim. Change, 97, 465-468, doi:10.1007/s10584-009-9593-3.

Reed, D. J., D. A. Bishara, D. R. Cahoon, J. Donnelly, M. Kearney, A. S. Kolker, L. L. Leonard, R. A. Orson, and J. C. Stevenson (2008), Sitespecific scenarios for wetlands accretion as sea level rises in the midAtlantic region, in Background Documents Supporting Climate Change Science Program Synthesis and Assessment Production 4.1, edited by J. G. Titus and E. M. Strange, Rep. EPA 430-R-07-004, sec. 2.1., U. S. Eniviron. Protect. Agency, Washington, D. C.

Rosati, J. D. (2005), Concepts in sediment budgets, J. Coastal Res., 21, 307-322, doi:10.2112/02-475A.1.
Roy, P. S., P. J. Cowell, M. A. Ferland, and B. G. Thom (1994), Wave-dominated coasts, in Coastal Evolution: Late Quaternary Shoreline Morphodynamics, edited by R. W. G. Carter and C. D. Woodroffe, pp. 121-186, Cambridge Univ. Press, Cambridge, U. K.

Ruggiero, P., and J. H. List (2009), Improving accuracy and statistical reliability of shoreline position and change rate estimates, J. Coastal Res. $25,1069-1081$, doi:10.2112/08-1051.1.

Sallenger, A. H. (2000), Storm impact scale for barrier islands, J. Coastal Res., 16, 890-895.

Sallenger, A. H., Jr., C. W. Wright, P. Howd, K. Doran, and K. Guy (2009), Extreme coastal changes on the Chandeleur Islands, Louisiana, during and after Hurricane Katrina, in Sand Resources, Regional Geology, and Coastal Processes of the Chandeleur Island Coastal System. An Evaluation of the Resilience of the Breton National Wildlife Refuge: Lafayette, LA, edited by D. Lavoie, U.S. Geol. Surv. Sci. Invest. Rep., 2009-5252, 27-36.

Schneider, S. H., and R. S. Chen (1980), Carbon dioxide warming and coastline flooding: Physical factors and climatic impact, Annu. Rev. Energy, 5, 107-140, doi:10.1146/annurev.eg.05.110180.000543.

Schwab, W. C., E. R. Thieler, J. R. Allen, D. S. Foster, B. A. Swift, and J. F. Denny (2000), Influence of inner-continental shelf geologic framework on the evolution and behavior of the barrier island system between Fire Island Inlet and Shinnecock Inlet, Long Island, New York J. Coastal Res., 16, 408-422.

Shaw, J., R. B. Taylor, D. L. Forbes, M.-H. Ruz, and S. Solomon (1998), Sensitivity of the coasts of Canada to sea-level rise, Bull. Geol. Surv. Can., 505, 1-79.

Shellenbarger Jones, A., C. Bosch, and E. Strange (2009), Vulnerable species: The effects of sea-level rise on coastal habitats, in Coastal Sensitivity to Sea-Level Rise: A Focus on the Mid-Atlantic Region, pp. 73-84, U.S. Clim. Change Sci. Program, Washington, D. C.

Smith, J. B., and D. Tirpak (Eds.) (1989), The potential effects of global climate change on the United States: Report to Congress, Rep. EPA 230-05-89-050, U. S. Environ. Prot. Agency, Washington, D. C.

Solomon, S., D. Qin, M. Manning, Z. Chen, M. Marquis, K. Averyt, M. Tignor, and H. Miller (Eds.) (2007), Climate Change 2007: The Physical Science Basis: Contribution of Working Group I to the Fourth Assessment Report on the Intergovernmental Panel on Climate Change, Cambridge Univ. Press, Cambridge, U. K.

Stockdon, H. F., A. H. Sallenger, R. A. Holman, and P. A. Howd (2007), A simple model for the spatially variable coastal response to hurricanes, Mar. Geol., 238, 1-20, doi:10.1016/j.margeo.2006.11.004.

Stolper, D., J. H. List, and E. R. Thieler (2005), Simulating the evolution of coastal morphology and stratigraphy with a new morphological-behavior model (GEOMBEST), Mar. Geol., 218, 17-36, doi:10.1016/j. margeo.2005.02.019.

Thieler, E. R., and E. S. Hammar-Klose E. (1999), National assessment of coastal vulnerability to future sea-level rise: Preliminary results for U.S. Atlantic Coast, U.S. Geol. Surv. Open File Rep., 99-593.

Thieler, E. R., O. H. Pilkey, R. S. Young, D. M. Bush, and F. Chai (2000), The use of mathematical models to predict beach behavior for coastal engineering: A critical review, J. Coastal Res., 16(1), 48-70.

Thieler, E. R., K. E. Anderson, D. R. Cahoon, S. J. Williams, and B. T. Gutierrez (2009), A science strategy for improving the understanding of sea-level rise and its impacts on U.S. coasts, in Coastal Sensitivity to Sea-Level Rise: A Focus on the Mid-Atlantic Region, pp. 185-192, U.S. Clim. Change Sci. Program, Washington, D. C.

Ticehurst, J. L., L. T. H. Newham, D. Rissik, R. A. Letcher, and A. J. Jakeman (2007), A Bayesian network approach for assessing the sustainability of coastal lakes in New South Wales Australia, Environ. Model. Softw., 22, 1129-1139, doi:10.1016/j.envsoft.2006.03.003.

Titus, J. G., and C. Richman (2001), Maps of lands vulnerable to sea level rise: Modeled elevations along the US Atlantic and Gulf coasts, Clim. Res., 18, 205-228, doi:10.3354/cr018205.

Titus, J. G., et al. (2009), Coastal Sensitivity to Sea-Level Rise: A Focus on the Mid-Atlantic Region, 320 pp., U.S. Clim. Change Sci. Program, Washington, D. C.

Tribbia, J., and S. C. Moser (2008), More than information: What coastal managers need to plan for climate change, Environ. Sci. Policy, 11, 315-328, doi:10.1016/j.envsci.2008.01.003.

Valverde, H. R., A. C. Trembanis, and O. H. Pilkey (1999), Summary of beach nourishment experience on East Coast barrier islands, J. Coastal Res., 15, 1100-1118.

Vermeer, M., and S. Rahmstorf (2009), Global sea level linked to global temperature, Proc. Natl. Acad. Sci. U. S. A., 106, 21,527-21,532, doi:10.1073/pnas.0907765106.

Weigend, A. S. (1994), Paradigm change in prediction, Philos. Trans. $R$ Soc. A, 348(1688), 405-418. 
Wilson, D. S., M. A. Stoddard, and K. J. Puettmann (2008), Monitoring amphibian populations with incomplete survey information using a Bayesian probabilistic model, Ecol. Modell., 214, 210-218, doi:10.1016/j.ecolmodel.2008.02.003.

Yin, J., M. E. Schlesinger, and R. J. Stouffer (2009), Model projections of rapid sea-level rise on the northeast coast of the United States, Nat. Geosci., doi:10.1038/ngeo462.
Zhang, K., B. C. Douglas, and S. P. Leatherman (2004), Global warming and coastal erosion, Clim. Change, 64, 41-58, doi:10.1023/B:CLIM. 0000024690.32682 .48

B. T. Gutierrez and E. R. Thieler, U.S. Geological Survey, 384 Woods Hole Rd., Woods Hole, MA 02543, USA. (bgutierrez@usgs.gov)

N. G. Plant, U.S. Geological Survey, 600 4th St. S, St. Petersburg, FL 33701, USA. 